NBER WORKING PAPER SERIES

\title{
COLLATERAL VALUATION AND BORROWER FINANCIAL CONSTRAINTS: EVIDENCE FROM THE RESIDENTIAL REAL ESTATE MARKET
}

\author{
Sumit Agarwal \\ Itzhak Ben-David \\ Vincent Yao \\ Working Paper 19606 \\ http://www.nber.org/papers/w19606
}

\author{
NATIONAL BUREAU OF ECONOMIC RESEARCH \\ 1050 Massachusetts Avenue \\ Cambridge, MA 02138 \\ October 2013
}

We benefited from the comments of Brent Ambrose, Effi Benmelech (NBER discussant), Joao Coco, Yongheng Deng, Ted Durant, Mike Faulkner, Paula Sapienza, Antoinette Schoar, Amit Seru, Susan Wachter, Wenlan Qian, Larry White, Yildiray Yildirim, and Luigi Zingales, as well as from those of seminar participants at the NBER Corporate Finance Meeting, Chicago Federal Reserve Bank, and Weimer School of Advanced Studies in Real Estate and Land Economics. The views in this paper are those of the authors and may not reflect those of Fannie Mae. Itzhak Ben-David gratefully acknowledges the financial support of the Dice Center at the Fisher College of Business, The Ohio State University, and of the Neil Klatskin Chair in Finance and Real Estate. The views expressed herein are those of the authors and do not necessarily reflect the views of the National Bureau of Economic Research.

At least one co-author has disclosed a financial relationship of potential relevance for this research. Further information is available online at http://www.nber.org/papers/w19606.ack

NBER working papers are circulated for discussion and comment purposes. They have not been peerreviewed or been subject to the review by the NBER Board of Directors that accompanies official NBER publications.

(C) 2013 by Sumit Agarwal, Itzhak Ben-David, and Vincent Yao. All rights reserved. Short sections of text, not to exceed two paragraphs, may be quoted without explicit permission provided that full credit, including $(\mathrm{C}$ notice, is given to the source. 
Collateral Valuation and Borrower Financial Constraints: Evidence from the Residential Real

Estate Market

Sumit Agarwal, Itzhak Ben-David, and Vincent Yao

NBER Working Paper No. 19606

October 2013

JEL No. D03,D1,D10,D12,D14,D18,G01,G02,G17,G2,G21,G23,G30,K20,L85,R2,R21,R3,R31,R51

\author{
ABSTRACT \\ Financially constrained borrowers have the incentive to influence the appraisal process in order to \\ increase borrowing or reduce the interest rate. We document that the average valuation bias for residential \\ refinance transactions is above 5\%. The bias is larger for highly leveraged transactions, around critical \\ leverage thresholds, and for transactions mediated through a broker. Mortgages with inflated valuations \\ default more often; however, lenders partly account for the valuation bias through pricing. \\ Sumit Agarwal \\ Associate Professor of Finance and Real Estate \\ NUS Business School \\ Mochtar Raidy Building, BIZ1 \\ 15 Kent Ridge Road \\ Singapore, 119245 \\ ushakri@yahoo.com \\ Itzhak Ben-David \\ Associate professor of finance and \\ Neil Klatskin Chair in Finance and Real Estate \\ Fisher College of Business \\ The Ohio State University \\ 2100 Neil Avenue \\ Columbus, $\mathrm{OH} 43210$ \\ and NBER \\ bendavid@fisher.osu.edu \\ Vincent Yao \\ Fannie Mae \\ 3900 Wisconsin Avenue, NW \\ Washington, DC 20016-2892 \\ vincent_w_yao@fanniemae.com
}




\section{Introduction}

Collateral is a central feature of the vast majority of credit contracts (e.g., Johnson and Stulz, 1985; Berger and Udell, 1990; Aghion and Bolton, 1992; Hart and Moore, 1994, 1998; Hart, 1995; Tirole, 2005; Benmelech and Bergman, 2009). Valuations are typically performed by experts, who have knowledge about the specific market. While experts attempt to provide unbiased opinions about the value of assets, they may be subject pressures to bias their valuation by the parties involved: lenders, intermediaries, or even borrowers. Although an extensive theoretical and empirical literature in corporate finance focuses on the contracting aspect of collateral, ${ }^{1}$ very little is known about the methodology for valuing collateral.

Experts' valuations, however, may be attenuated by financially-constrained borrowers. Those borrowers are likely to be motivated to maximize the debt capacity of their assets or to minimize their interest payments, and they can do so by influencing the valuation process; a higher valuation for an asset means a higher debt capacity and a lower interest rate. ${ }^{2}$ If such influence indeed exists, then the observed leverage of originated loans (measured as the loan-tovalue ratio) could be underestimated (since the valuation component is overestimated). ${ }^{3}$ While anecdotal evidence suggests such pressure by and on behalf of borrowers, no systematic study

\footnotetext{
${ }^{1}$ Economic theory explains the role of collateral in debt contracts as an attempt to mitigate agency costs or contracting frictions in a world with asymmetric information. Chan and Thakor (1987) argue that collateral alleviates the adverse selection problem, while Holmstrom and Tirole (1997) argue that collateral alleviates the moral hazard problem. Inderst and Mueller (2007) show that collateral allows local banks that use soft information to be more competitive than banks that use hard information in their lending. Benmelech, Garmaise, and Moskowitz (2005) find that liquidation values of collateralized assets are first-order determinants of loan contract terms. Vig (2013), using a natural experiment, finds that strengthening creditor rights forces firms to alter their debt structure. Berger, Espinosa-Vega, Frame, and Miller (2011) present empirical evidence that the introduction of information technology reduced the incidence of using collateral in lending, suggesting that collateral solves an asymmetric information problem.

${ }^{2}$ Rajan, Seru, and Vig (2013) find evidence that lenders, when making lending decisions, put a lot of weight on observable "hard" information such as asset values.

${ }^{3}$ For a broader literature on the evidence linking the creation of the real estate bubble in the early 2000s to misaligned incentives, see Mian and Sufi (2010), Haughwout, Lee, Tracy, and van de Klaauw (2011), Keys, Mukherjee, Seru, and Vig (2010), Agarwal and Ben-David (2012), Mayer, Pence, and Sherlund (2009), Agarwal, Chang, and Yavas (2012), Piskorski, Seru, and Vig (2010), and Agarwal, Amromin, Ben-David, Chomsisengphet, and Evanoff (2011).
} 
has examined the phenomenon and quantified the economic effect. Thus, the goal of this paper is to measure the effect of borrowers' pressure to inflate valuations in the residential housing market.

Lenders in the real estate market rely heavily on experts (called appraisers) in estimating the value of the collateral, especially in refinance transactions. In purchase transactions, lenders typically consider prices of purchase transactions as reflecting unbiased market valuations, but to prevent fraud, they often request an appraisal to verify that the purchase price is reasonable. In refinance transactions, however, there is no market price available; thus, lenders rely solely on appraisers to determine the value of the collateral. In residential real estate, appraisers primarily determine this value by compiling recent purchase prices of comparable assets—a method that is subjective, as appraisers have a lot of leeway in determining which properties to use as comparables.

While it is hard to determine whether pressure on appraisers comes directly from borrowers, or through intermediaries and lenders, we can measure the size of the bias using a dataset of transactions and appraisals. Our estimation approach relies on comparing purchase prices of properties to previous valuations of refinance (refi) transactions for the same property. Like appraisers, we assume that prices of purchase transactions reflect an unbiased estimate of the property value. Thus, the difference between the sales price and the valuation used in the preceding refi transaction reflects a valuation bias. To account for systematic trends in home prices, we also include in our sample prices of pairs of purchase transactions for the same properties.

We apply our measurement methodology to a large sample of more than one million pairs of conforming mortgage transactions that were originated between 1990 and 2011. We find that 
valuations in refinance transactions are $4.6 \%$ higher for rate and term refis and about $6.8 \%$ higher for cash-out refis, compared to the prices of purchase transactions on the same properties.

The bias is stronger when the parties involved in the transaction have stronger incentives to bias valuations. We document that the magnitude of the bias is positively correlated with the leverage of borrowers. This relationship, however, weakens once we control for location and time fixed effects, presumably because these controls are highly correlated with refinance activity interacted with leverage. We show that the relation between the valuation bias and leverage is especially strong in nonrecourse states where borrowers are not personally liable for the mortgage balance, perhaps because borrowers see a smaller downside to influencing appraisers in those states.

To understand the economic mechanism better, we study the determinants of the bias in the cross-section of properties. We find that the magnitude of the valuation bias is affected by the incentives of mortgage originators and borrowers in four primary ways. First, refinance mortgages that were originated by third-party originators (e.g., mortgage brokers) have an extra valuation bias of about 2.0 percentage points. These originators sell all of their loans to aggregators and therefore do not bear the liability from borrower default. They thus are more willing to influence the valuations in order to close the deal. Second, there are strong lender fixed effects: some lenders are persistently more prone to valuation bias than others. We document that the valuation bias is stronger among lenders who had exhibited strong bias in the past. Third, the magnitude of the valuation bias decreases dramatically as loan sizes approach the jumbo-loan cutoff limit. Close to this threshold, borrowers have weaker motivation to inflate valuations, as the size of the loan is already limited. Fourth, the magnitude of the valuation bias is higher for rate/term refinance loans that are at or below the leverage thresholds at which mortgage rates 
increase. This finding is consistent with the idea that these borrowers influence appraisals to reduce their mortgage costs.

We next investigate whether valuation bias is related to default. Indeed, we find evidence supporting our hypothesis that the likelihood of default is higher for transactions in which valuations are inflated. To understand whether correcting for the valuation bias better explains default patterns, we conduct a horse race between the observed leverage and the estimated true leverage. The correction is made according to the type of mortgage, leverage, and origination channel. Our results show that the bias-corrected leverage contains additional information about the likelihood of default that is not contained in the observed leverage. This result explains why cash-out refinance loans pose greater credit risk (Elul, Souleles, Chomsisengphet, Glennon, and Hunt, 2010) and are subject to stricter eligibility requirements and higher fees (Freddie Mac, 2012).

Finally, we explore whether lenders charge higher interest rates to compensate for the higher risk of default among loans with valuation bias. We find that lenders, indeed, charge higher rates for mortgages that have higher valuation bias. Our analysis shows that controlling for interest rate, and its polynomials, capture all the variation in valuation bias, thus demonstrating that lenders partly accounting for valuation bias through pricing.

Given that lenders appear to be aware of the valuation bias and adjust their interest rates accordingly, we are intrigued by the role of valuation inflation in the lending process. Why do financially constrained borrowers not simply borrow larger amounts without needing to put pressure on lenders and appraisers? The main reason is that lenders are bound to $100 \%$ LTV lending by regulators (in case of banks) ${ }^{4}$ or the practice of the secondary market. If lenders did

\footnotetext{
${ }^{4}$ For example, see bank restrictions on loan-to-value by property type: http://www.fdic.gov/regulations/laws/rules/2000-8700.html
} 
not tolerate valuation inflation, they could lose business from financially constrained borrowers, a large segment of the market. In turn, some borrowers likely would not refinance their mortgages unless they received attractive valuations on their houses. ${ }^{5}$ Hence, lenders effectively collude with borrowers to lend them larger amounts than dictated by capital providers. This idea is consistent with Zingales' (2012) claim that lenders bent the rules during the credit boom period (early 2000s) to expand the supply of credit.

There are two concerns with our empirical methodology: potential selection bias into the sample, and potential changes over time in the quality of transacted homes. We run additional tests to verify that our results are not affected by these factors. The tests show that the results are largely robust.

Overall, our results are consistent with the idea that financially constrained borrowers influence valuations of collateralized assets. Valuations in refinance transactions are systematically inflated relative to purchase transactions, and therefore have higher leverage than what can be observed by outsiders. Although collateral valuation seems like a piece of hard information (see Petersen, 2004), it is subject to manipulation. This effect is especially pronounced for highly leveraged transactions and for mortgages originated by third-party originators. Our results suggest both that borrowers adversely select into the contract and that lenders are aware of the inflation of collateral values and price mortgages accordingly.

The question of attenuation of collateral valuation relates also to the growing literature about the manipulation of asset values and credit quality during the housing boom. Ben-David (2011) presents evidence that homebuyers collude with home sellers to inflate transaction prices

\footnotetext{
${ }^{5}$ In Figure 1 we present evidence for the demand for leverage: the plot shows the fraction of mortgages that were originated with $100 \%$ loan-to-value in Loan Performance database (securitized subprime and Alt-A loans) as well as in our dataset (conforming loans). The plot shows that during the credit expansion years, the fraction of 100\% LTV loans increased dramatically: by 25 percentage points for the subprime loan data, and by 15 percentage points for the confirming loan data.
} 
in order to increase the debt capacity of the house. Also, Jiang, Nelson, and Vytlacil (2009) provide evidence that borrowers inflate their personal income, and Garmaise (2012) shows that borrowers inflate their reported personal assets. Agarwal, Ben-David, Amromin, Chomsisengphet, Evanoff (2013) document that predatory lending (i.e., manipulations by lenders) was an important factor in borrower default during the financial crisis. Griffin and Maturana (2013) and Piskorski, Seru, and Witkin (2013) document that mispricings (such as unreported second liens, appraisal overstatements, owner occupancy misreporting, and flipping) were common in securitized mortgage pools. Furthermore, these studies find that manipulation activity is associated with a higher probability of default. More broadly, the valuation process of any asset is potentially biased by pressures from the parties involved. Bolton, Freixas, and Shapiro (2007) offer a general model for expert advice and conflict of interest. Michaely and Womack (1999) show conflict of interest in security analysts' opinions around IPOs. Allen, Jagtiani, Peristiani, and Saunders (2004) find evidence for conflict of interest by banks as advisors in mergers. White (2010) discusses the pressure that credit rating firms experience from bond issuers.

\section{Background}

\subsection{The Role of Appraisers in the Lending Process}

The real estate market has several characteristics that lead participants to seek the opinion of experts (appraisers) regarding the valuation of assets that serve as collateral. Assets in the real estate market are unique: no two properties are identical, and they can be distinct in their location, size, interior and exterior conditions, quality of construction, style, age, etc. Also, the property market is thin in the sense that properties typically change hands infrequently, every 
few years. There are about 110 million residential properties in the United States, but only 5\% transact every year. Because the customary leverage in the real estate market is high, typically 80\% loan-to-value or higher in the United States, it is important for the lender to have a precise estimate of the value of the collateral.

Banks typically hire appraisers to estimate the value of properties that are candidates for financing. In the residential market, appraisers base their opinion on comparable sales (“comps"). Appraisers use three to five comparable assets to estimate the value of the subject property by comparing their characteristics. The comps are properties with physical characteristics similar to the asset in question that were transacted in recent months. When the comps have characteristics distinct from those of the asset in question that could affect the price (e.g., the number of bedrooms), appraisers manually make adjustments to the price to reflect these differences. This method is the most relied-upon type of appraisal in the residential market. This method is equivalent to a hedonic model of valuation that an econometrician would use, only with a very small sample. In addition to the appraisal, some banks use an automated valuation model (AVM), ${ }^{6}$ which is essentially a hedonic model. In the appraisal process, the appraiser must make many assumptions, allowing for a great deal of discretion. For example, the appraiser has the latitude to select the properties that appear to be the best comparables. Because properties can resemble each other on many dimensions, the appraiser can always distort his or her choice of comparable assets.

Most real estate lending transactions include valuations prepared by appraisers, but appraisers' opinions hold more weight in refinance transactions than in purchase transactions. In purchase transactions, banks rely primarily on the transaction price. The price is also a proxy for

\footnotetext{
${ }^{6}$ AVMs are statistical models that predict property values based on transaction prices of nearby properties with similar characteristics. The models are typically based on a hedonic regression analysis.
} 
the fundamental value; it is likely to be unbiased, because typically it reflects an arm's length transaction. In purchase transactions, the role of the appraiser is to provide another approximation for the fundamental value and verify that the transaction price presented to the bank is not fraudulent. In refinance transactions, however, there is no transaction price and banks rely exclusively on appraisals.

\subsection{Valuation Bias}

Given the uncertainty and the discretion in the appraisal process, valuations can be considered a noisy proxy for the fundamental value of assets. We therefore wonder about the quality of valuations: are they good proxies for the fundamental values of assets, and in particular, are they biased in a predictable way? What are the economics behind the bias?

The hypothesis that we test is that appraisers bias valuations of residential real estate properties upward to cater to borrowers, potentially through intermediaries. Specifically, prospective borrowers demand high valuations when they are highly leveraged because higher valuations allow them to borrow more and at a lower rate. Intermediaries agree to put pressure on appraisers, because it increases the odds that the client would be satisfied and close the deal.

We expect to find bias in refinance transactions because they rely solely on appraisals to determine the value of the collateral.

Much anecdotal evidence suggests that such a bias exists. For example, a recent wellknown legal case of systematic biases in appraisals involved Washington Mutual (a lender) and eAppraiseIT (an appraisal management company). In November 2007, New York Attorney General Andrew Cuomo filed suit against Washington Mutual alleging that between July 2006 and April 2007 the firm put pressure on its appraisal management company, eAppraiseIT, to 
generate high appraisals. Washington Mutual threatened to transfer business to eAppraiseIT’s competitors and in a number of cases actually discontinued its contract. eAppraiseIT bowed to Washington Mutual and produced a list of "proven accepted" (by Washington Mutual) appraisers. Other appraisers did not receive appraisal assignments. ${ }^{7}$

Recent legislation (the Dodd-Frank Act) and new industry standards acknowledge the existence of appraisal bias and attempt to address it. ${ }^{8}$ In May 2009, both Fannie Mae and Freddie Mac announced the Home Valuation Code of Conduct to establish a firewall between appraisers and loan officers. Since then, both companies have invested millions of dollars in developing new appraisal data standards, forms, and tools; requiring more due diligence on the part of both banks and appraisers; and enforcing stricter rules governing how appraisals should be done (Fannie Mae, 2012). In addition, in late 2010, as a requirement of the Dodd-Frank Act, the Federal Reserve announced a number of new rules to ensure that real estate appraisers are free to use their independent professional judgment in assigning home values without influence or pressure from those with an interest in the transactions (Federal Reserve, 2010).

One wonders why lenders and brokers are willing to influence the appraisal process on behalf of financially constrained borrowers. One explanation relates to the optionality of refinancing. Borrowers who apply for refinancing can typically carry on with their current mortgage. Refinancing improves their position, but only at the margin. Furthermore, they have the leisure to shop for the best deal, and, in some cases, not to engage in the transaction at all. Thus, loan officers in essence compete for the business of refinancing borrowers. Much evidence

\footnotetext{
7 See Wamu-eAppraiseIT case coverage on http://www.reuters.com/article/2012/09/28/us-appraisal-settlementidUSBRE88R02520120928. Also, other media resources include http://www.washingtonpost.com/wp-dyn/content/article/2007/02/02/AR2007020200712.html, http://www.myrecordjournal.com/latestnews/article_15198981-28a6-575f-9b68-b93a607e64c4.html, http://www.mortgagenewsdaily.com/4252005_Appraisal_Fraud.asp.

${ }^{8}$ See Donna Borak, “Rules set for ‘independent appraisers,'” American Banker, December 3, 2010. See also http://www.mortgagenewsdaily.com/5112005_Aprraisers_On_Pressure_And_Reform.asp and http://www.publicintegrity.org/2009/06/17/2842/despite-new-rules-appraisers-say-pressure-remains.
} 
of this behavior emerged during the real estate bubble, when advertisements for the refinancing to highly leveraged mortgages were common.

Furthermore, the parties involved in the origination process have incentives that induce them to approve loans that are undercollateralized. As discussed earlier, appraisers' assignments used to be for decades, until 2010, in the hands of loan officers, hence, appraisers did their best not to be an obstacle from a deal to happen. Loan officers are often incentivized by origination volume (Agarwal and Ben-David 2012).

It is possible that lenders' reputation would enact as a counter force, and prevent moral hazard problems such as valuation bias (e.g., Pennacchi, 1988; Gorton and Pennacchi, 1995). However, evidence from the industry about blacklisting practices and our empirical evidence suggest that moral hazard problems in the banking industry do exist in lending, thus reputation is not sufficient to mitigate those problems.

\section{$3 \quad$ Measuring the Appraisal Bias}

Our approach to estimating the magnitude and effects of the appraisal bias is based on comparing a property sale price to an earlier valuation from a refinance transaction of the same property. The basic premise of the analysis is that a sale price provides an arm's length unbiased valuation of the property and therefore can serve as a benchmark valuation. ${ }^{9}$ The valuation used in a refinance transaction could potentially be biased. Therefore, the log difference in values between the initial valuation of the refinance transaction and the subsequent purchase transaction serves as a proxy for valuation bias.

\footnotetext{
${ }^{9}$ Appraisals are also used in purchase transactions; however, these usually converge to the transaction price or above. Cho and Megbolugbe (1996) find that $95 \%$ of appraisals are either equal to the sale price (30\%) or above it (65\%).
} 
As a control sample, we use pairs of consecutive purchase transactions to estimate the difference in values in the absence of a refinance transaction. Thus, each observation in our sample reflects the log difference in values, either between an initial refinance transaction and a subsequent purchase transaction, or between two purchase transactions for the same property.

Because we compare valuations of the same property over time (either in the form of a sale price or an appraisal), we need to account for changes in general market valuations. We address this issue by including a control for the time passed between the transactions and by including two sets of fixed effects: a set of fixed effects for the interaction of the MSA (Metropolitan Statistical Area) with the calendar quarter for each of the transactions in the pair. These two sets of fixed effects capture the level of market valuations at the MSA calendarquarter level. Thus, our controls remove the market component of valuation changes from the dependent variable.

The measurement methodology we propose relies on the assumption that homeowners decide on when to refinance their properties independent of future returns of the property. This assumption is also likely to be valid, since the properties are valued by professional appraisers. It is implausible that homeowners have better information on average about the market than market professionals.

In a regression framework, this measurement methodology translates to the following sample and variables. Our sample includes two types of pairs of transactions for the same property: an initial refinance transaction followed by a purchase transaction, or two successive purchase transactions. For each pair, we compute the log difference in values. This is our dependent variable. Our main prediction is that the log difference in values will be significantly larger for refinance-purchase pairs than for purchase-purchase pairs. Hence, the explanatory 
variables are the refinance dummies (either cash-out refinance or rate/term refinance), along with many other controls. In our specification, the coefficient on the refinance dummy should be positive-indicating that appraisals are inflated in the initial refinance transactions compared to purchase-purchase pairs.

\section{$4 \quad$ Data}

\subsection{Data Sources}

Our main body of data comes from two sources. First, we collect mortgage information about the first transaction in each pair using the universe of mortgages that were securitized from 1990 to 2011. These are conventional not government loans. These mortgages are conforming loans made to borrowers with a relatively high credit score (620 or higher). Conforming mortgages meet the conforming loan limit, which has been $\$ 417,000$ since 2006 for a one-unit, single-family dwelling. We exclude borrowers with credit scores below 620 . The original dataset includes about 14.1 million transactions. Relative to other datasets of securitized loans used in the literature such as LoanPerformance or McDash, our dataset contains loans of higher credit quality (e.g., higher FICO scores, lower LTVs).

The second dataset consists of purchase transactions only. Because we do not require mortgage information for these transactions and because we wish to maximize the sample size, we supplement the loan-level data with public records (e.g., records of deeds) for the second transaction in each pair.

Our final dataset is composed of pairs of transactions for the same property. There are two types of transaction pairs that are of interest: a refinance (either cash-out or rate/term refinance) transaction followed by a purchase transaction, and a purchase transaction followed 
by a purchase transaction. As explained in Section 3, our interest is in the first transaction because we use it to measure the valuation bias. For each pair, we record the transaction dates, the origination channel of the first transaction, and the characteristics of the mortgage.

In one of the robustness tests, we compare valuations made by appraisers to valuations made by AVMs. For this test, we do not require pairs of transactions, but rather require that individual transactions have valuation estimates produced by both appraisers and AVMs. These data have characteristics similar to the dataset described above: loans were originated between 1990 and 2011, and are conventional loans below the conforming loan limit.

\subsection{Summary Statistics}

The summary statistics are presented in Table 1 . The average sales price for the second transaction is $\$ 217,000$. The average sales price for the second transaction is $\$ 241,000$. When examining the first transaction in each pair, we find that cash-out refis account for $25 \%$ of all transactions, rate/term-refis make up $34 \%$ of all transactions, and the rest are purchase transactions. We find that $51.6 \%$ of transactions were sourced by third-party originators (TPOs: e.g., mortgage brokers and correspondent banks) for the purpose of selling in the secondary market; the rest of the loans were sourced by lenders who keep some loans on their books.

The average combined loan-to-value ratio (CLTV) in the first transaction in each pair is relatively low (75.8\%). About 30\% of loans have very low CLTV ( $\leq 70 \%)$. Approximately $19 \%$ of loans have CLTV greater than $70 \%$ and lower than $80 \%$, and another $18.4 \%$ are concentrated at $80 \%$ CLTV. In the dataset, $3.5 \%$ of loans have CLTV greater than $80 \%$ and lower than or equal to $85 \%$, and $11.4 \%$ have leverage greater than $85 \%$ and lower than or equal to $90 \%$. About 
$10.5 \%$ have leverage greater than $90 \%$ but lower than $95 \%$, and the remaining $7 \%$ have CLTV greater than $95 \%$ and lower than or equal to $100 \%$.

Loan quality of the first transaction in each pair is relatively high. The average FICO credit score is 715 . A total of $12.1 \%$ of loans in the second transaction ended up in default or foreclosure, and $14.4 \%$ of properties were sold when the borrowers were in serious delinquency (60+ days past due).

\section{$5 \quad$ Empirical Analysis}

\subsection{Estimating the Valuation Bias}

We begin by estimating the valuation bias for the entire sample. In Table 2, we regress the change in valuation between a sale and a previous transaction (either a sale or refinance) for the sample property. The variables of interest are the refi indicators of the previous transaction: either a cash-out refi ${ }^{10}$ or a rate/term refi.

We present three generic specifications in Table 2. In Column (1) we regress the log difference in transaction values on cash-out and rate/term refi indicators as well as indicators of whether the price in the subsequent transaction is associated with a default or a serious delinquency. These indicators have coefficients because a default or delinquency means that the property is likely to be foreclosed upon and probably sold at a significant discount (Campbell, Giglio, and Pathak, 2011; Harding, Rosenblatt, and Yao, 2009, 2012), making the initial transaction appear to have a relatively high valuation. Without these indicators, the discount of a distressed sale in the second transaction would have been attributed to a valuation bias in the initial transaction. In Column (2) we add property- and mortgage-level characteristics. These

\footnotetext{
${ }^{10}$ Greenspan and Kennedy (2008) categorize the uses of cash from cash-out refinancing as financing consumer spending, outlays for home improvements, debt repayment, and acquisition of assets.
} 
characteristics relate to the first transaction in the pair. In Column (3) we add two series of fixed effects: for the MSA interacted with the quarter of the initial transaction and for the MSA interacted with the quarter of the subsequent transaction.

We focus on Column (3), which controls for property- and mortgage-level characteristics as well as for fixed effects. Purchase-purchase pair is the benchmark category. Compared to this benchmark, the valuation bias is about $6.8 \%$ of property values for cash-out refis and is $4.6 \%$ for rate/term refis. These findings suggest that there is a significant valuation bias between appraisals for refinance transactions and contract prices of purchase transactions; in addition, the bias is larger for cash-out refis, potentially because homeowners who look to extract equity from their homes more strongly demand higher valuations.

Overall, these estimates show that valuation bias is economically important. Given that $25 \%$ of all mortgage transactions are cash-out refi transactions and $34 \%$ are rate/term refi transactions (Table 1), our results indicate that the bias is economically material.

\subsection{Leverage and Valuation Bias}

To test the hypothesis that valuation bias increases with borrowers' leverage, we regress our measure of the valuation bias (the log difference of values) on cash-out and rate/term refi dummies interacted with leverage dummies, in addition to controls and fixed effects. The regressions are presented in Table 3, Columns (1) to (3). They show that the valuation bias generally increases with leverage. In Columns (1) and (2), which include controls but no fixed effects, the coefficients increase almost monotonically with leverage dummies, indicating that the valuation bias increases with leverage. In Column (3), the additional fixed effects appear to covary with the refi dummies that are interacted with the high leverage dummies, and thus the 
coefficients on the dummies of the very high leverage categories have smaller coefficients than those in Columns (1) and (2).

To illustrate the magnitude of the effect, compare the valuation bias for low- versus highleverage refinanced loans. Compared to cash-out refi loans with leverage lower than or equal to $70 \%$, loans with leverage greater than $95 \%$ have a valuation bias that is higher by $6.7 \%$ (Column (1)), or by 3.5\% and $0.6 \%$ (Columns (2) and (3), respectively). The differences in the coefficients for rate/term refis are smaller.

Why does the valuation bias decline at high leverage ratios? One possibility is that there are factors that reduce the demand among some highly leveraged borrowers for high valuations. One such factor could be the recourse status of the state. In recourse states, the lender can pursue other assets of borrowers in the event of default, thus increasing their cost of default; other states do not have such a provision. Our prediction is, therefore, that mortgages originated on homes in states that have a recourse clause have lower valuation bias than mortgages originated in nonrecourse states. This effect should be especially strong for highly leveraged mortgages, for which the ex-ante risk of default is more probable.

To test whether this factor has an effect on the valuation bias, we split the sample into recourse and nonrecourse mortgages and rerun the analysis from Table 3, Column (3). The results are presented in Columns (4) and (5). As expected, valuation bias is significantly higher for highly leveraged borrowers in states with nonrecourse provisions relative to those with recourse provisions. In nonrecourse states, the valuation spread between cash-out mortgages with leverage of 70\% CLTV and below, and mortgages with leverage of 95\% CTLV or above is nearly $4 \%$. 
Finally, we test whether valuation bias is associated with the information quality of the loan. In Table 3, Columns (6) and (7), we split the sample by the documentation level of the mortgages (low vs. full) and reran the analysis. The results show that valuation bias is significantly stronger for the low-documentation population, suggesting that this bias is correlated with the overall quality of mortgages. This is a bad news for lenders, since mortgages with low-level of documentation are more likely to default (e.g., since borrowers lied about their income; Jiang, Nelson, and Vytlacil 2009), and now we show-are more likely to have their collateral value overvalued.

In sum, borrower leverage is correlated with the extent of valuation bias. This finding is consistent with the idea that financially constrained borrowers demand higher appraisals on refinance transactions, especially in nonrecourse states.

\subsection{Variation in the Incentives to Influence Valuations}

Next, we explore several situations in which borrowers' incentives to influence valuations are modified.

\subsubsection{Retail versus Third-Party Originators}

Loans in our dataset are originated through two channels: a lender's own retail branches or through third-party originators (TPOs), including brokers and correspondent lenders. Whereas lenders originate loans either to keep them on their balance sheets or to sell them to mortgage securitizers, TPOs originate loans for the sole purpose of selling them, without intending to keep any. 
Given the difference in the exposure to default risk, we anticipate that the degree of the bias in valuation will be greater for loans that were originated by third-party originators. Although all mortgages in our dataset were securitized, we can distinguish between mortgages that were originated by third-party originators or by retail lenders. In Table 4, Panel A, Column (1), we regress the log difference of valuations on refi dummies interacted with an indicator of whether the loan was originated by a third-party originator. The regressions show that refi mortgages that were originated through a third-party origination channel have significantly higher valuations by $1.7 \%$.

\subsubsection{Lenders' Attitudes toward the Screening Process}

The ability of borrowers to influence appraisals depends largely on the attitudes that lenders have toward the screening process. If the screening procedure is perceived as an important element in the underwriting process that reflects on the reputation of the lender, then lenders are likely to resist the attempts by borrowers to influence the appraisal. Conversely, some loan officers may view the screening process as a hurdle that needs to be overcome, perhaps because their compensation structure incentivizes them to do so (Agarwal and Ben-David, 2012). In these cases, loan officers would apply pressure on appraisers in order to satisfy their mortgage applicants.

Attitudes toward the screening process are likely to be embedded in the lenders' organizations and therefore should display persistence over time. To test this conjecture, we estimate the lender fixed effects for the valuation bias in each year, and then determine whether these fixed effects correlate with the valuation bias on future originations. Specifically, in the first stage of the analysis, we run a regression of the log difference of values on the usual 
controls and lender fixed effects for each calendar year (according to the origination year of the first mortgage in each pair). Then, for each year, we sort these fixed effects into deciles and scale them to be between 0 and 1 , with a high rank indicating high past valuation bias. ${ }^{11}$ In the second stage of the analysis, we regress the log difference in values on interactions of refinance indicators and the lender ranking.

The results of the analysis are presented in Table 4, Panel A, Column (2). The regression shows that valuation bias is persistent at the lender level, i.e., lenders whose previous refinance originations had a high valuation bias also would have such a bias in their future originations, on average. The economic effect is large. The spread in valuation bias between lenders who have a history of high valuation bias to those who do not is in the magnitude of $1.0 \%$ to $2.2 \%$ of asset values.

\subsubsection{Lender Market Competition}

The level of competition in the lenders' market is potentially an important factor determining valuation bias. To test for this channel we conduct two tests. In the first test we use HMDA dataset to calculate a Herfindahl-Hirschman Index (HHI) for the concentration of the lending market at the MSA level. For each MSA-year we count the number of lenders and the number of loans each generated. Then, the HHI variable is calculated by summing the squares of the percentage market shares held by the respective lenders. For example, an industry consisting of two firms with market shares of $70 \%$ and $30 \%$ has an $\mathrm{HHI}$ of $\left(70^{2}+30^{2}\right) / 1000$, or 5.8 , where higher values correspond to greater concentration in the market. Since HMDA is available to us since 2000, the analysis is restricted to 2000-2011.

\footnotetext{
${ }^{11}$ We note that this analysis cannot be done in real time, because the dependent variable includes information from the future: the log difference in values between the first and second transactions. The sample in this regression has only 714,892 observations because we require at least ten transactions per lender in the preceding year.
} 
In Table 4, Panel A, we regress the valuation bias on the interaction of refinance indicators and HHI. The results show that the coefficient is positive, suggesting that valuation bias is stronger for local markets in which competition is lower. The effect is minor in magnitude: one standard deviation increase in $\mathrm{HHI}$ is associated with a bias higher by $0.5 \%$. The direction of the effect can be rationalized if lenders are interested to provide high valuations (to expand their lending market), and put pressure on appraisers to comply.

\subsubsection{Maximum Loan Size}

Another dimension in which borrowers' incentives vary is the dollar size of the loan with respect to the maximum loan size allowed. Specifically, the federal government sets a conforming loan limit on an annual basis; this cap has increased over time but has held at $\$ 417,000$ since 2006.

This cap on loan size allows us to test borrowers’ motives for influencing the valuation of the underlying assets. By inflating the value of the asset, borrowers can borrow a larger amount, because lenders often determine the maximum loan amount as a fraction of the value of the underlying asset (i.e., loan-to-value ratio). Also, with a larger property valuation, borrowers can benefit from a lower interest rate because loans with lower CLTV generally have lower interest rates. When a loan reaches the dollar size cap, then the first motive is shut off: there is no point in influencing the valuation in order to borrow more. The second motive, however, still exists.

We therefore predict that loans that are closer to the jumbo-loan cutoff have smaller valuation bias. The prediction is tested in Table 4, Panel B. We stratify the sample by the ratio of the loan size to the jumbo-loan cutoff for the relevant year. The results show that cash-out refi loans that are close to the conforming loan limit have a $4.2 \%$ valuation bias, relative to a 
valuation bias of $6.9 \%$ for loans at or below $85 \%$ of the jumbo-loan cutoff. Rate/term refi loans exhibit a sharp decline in the valuation bias, from $4.8 \%$ for low loan values to $0.6 \%$ for loans near the jumbo-loan cutoff. One explanation for the different behavior between cash-out and rate/term refis is that cash-out refi borrowers' objective is to maximize the amount that they withdraw and therefore the jumbo-loan cutoff drastically reduces their motive to influence valuations. Conversely, rate/term refi borrowers' objective is to lower the rate that they pay; hence, even given a maximum loan value, it still might be worthwhile for some borrowers to push the valuation to benefit from better financing terms.

\subsubsection{Leverage Thresholds}

Another way to test our hypothesis that borrowers influence appraisals to benefit from better interest rates is to exploit the discontinuities in mortgage rates with respect to the combined loan-to-value ratio. Specifically, mortgage rates increase when leverage surpasses $85 \%, 90 \%$, and $95 \%$. Our hypothesis therefore predicts that borrowers have a stronger incentive to influence appraisals when the inflated valuation would push them to a lower mortgage rate, i.e., below a mortgage threshold. In particular, this incentive is stronger for borrowers seeking rate/term refis. For these borrowers, there is no need to inflate the appraisal value beyond the valuation associated with their original mortgage; they have, however, strong motivation to refinance their mortgage to a lower rate.

To test this prediction, we stratify the sample around these thresholds and include mortgages that have a cumulative CLTV of $\pm 1 \%$ around each threshold. Then, we test whether mortgages that are at or below each threshold have higher valuation bias. The results are

presented in Table 4, Panel C. The regressions show that the coefficients on the interaction of 
at/below leverage cutoff and rate refi are always positive and statistically different from zero for rate/term refi transactions. In addition, the magnitude of the coefficients increases with the leverage ratios. Thus, consistent with our hypothesis, rate/term refi mortgages that are at or below a threshold have a greater valuation bias.

\subsubsection{Time Series of Valuation Bias}

We next portray the time series of valuation bias. To do so, we split the sample by the date of the first transaction (refinance or purchase), and rerun the main tests. The results are presented in Table 4, Panel D. The results show that the valuation bias was relatively modest in the 1990 s (5.3\% for cash-out refis and 3.8\% for rate refis). It increased in the early $2000 \mathrm{~s}$ ( $8.0 \%$ for cash-out refis and 6.0\% for rate refis), declined and bottomed in 2004 (5.6\% for cash-out refis and 3.0\% for rate refis) and increased again since then. In the years following the real-estate boom period, when the real-estate market was in decline (2007-2011), the valuation bias was very high (9.3\% for cash-out refis and $7.5 \%$ for rate refis). A potential reason for this is that appraisers use comparable assets from previous months, when prices were higher.

\section{Borrower Default and Valuation Bias}

The valuation bias has the potential of being an important determinant for borrower default. If valuations of refinance transactions are inflated, then their observed leverage should be downward biased. The prediction is therefore that loans with more severe valuation bias are more likely to default. Such a result would be consistent with the finding of Lacour-Little and Malpezzi (2003) that appraisals that are higher than valuations predicted by a hedonic model 
predict future borrower default. Similarly, Kelly (2007) shows that discrepancy between actual appraisals and AVMs is associated with future borrower default.

In this section, we test this prediction using a two-stage procedure. The idea is to run a default regression as is customary in the literature (i.e., on indicators of the observed CLTV and on mortgage characteristics), and then test whether the residuals of this regression contain additional information that can be explained by the CLTV recalculated based on the deflated property value. $^{12}$

We begin with a base specification in Table 5, Column (1), which is the standard default regression (e.g., see Ambrose and Capone, 1998; Deng, Quigley, and Van Order, 2000). The dependent variable is a dummy indicating whether the mortgage defaulted in the first 12 months after origination. The independent variables include mortgage characteristics ${ }^{13}$ as in previous regressions, as well as fixed effects for MSA interacted with calendar quarter. We use a probit regression, and the table presents the marginal effects. As expected, the likelihood of borrower default increases with the observed CLTV.

Then, we regress the residuals from the first-stage regression on leverage indicators that reflect the recalculated leverage based on the deflated asset values. We recalculate the CLTV as the loan divided by the recalculated value, where the recalculated value is deflated for refi transactions according to their relevant values based on the coefficients in Tables 3 and 4, Panel A, Column (1). For example, we adjust down the value of initial cash-out and rate/term refi transactions that were originated by third-party originators by a factor of $1.7 \%$, as appears in Table 4, Panel A, Column (1).

\footnotetext{
${ }^{12}$ We cannot perform the horserace in one regression since the correlation with the observable LTV and the recalculated LTV is often greater than $80 \%$ resulting in multicollinearity.

${ }^{13}$ Control variables include FICO score, indicators for mortgage products (30-year FRM, 15-year FRM, ARM), an investor dummy, a condo dummy, the excess premium, and the debt-to-income ratio.
} 
The results of the regression of the residuals on the indicators of the recalculated CLTV values are presented in Table 5, Column (2). The regression shows that the residuals of default increase with the recalculated leverage. This means that the recalculated leverage contains information that is not captured in the observed leverage.

\section{$7 \quad$ Is the Valuation Bias Priced by Banks?}

Lenders typically measure the risk of loans based on three primary variables-loan purpose, credit score (FICO), and leverage-and price them accordingly. ${ }^{14}$ An important empirical question is whether lenders are aware of the distortion created by the valuation bias and attempt to price for it.

To answer this question, we test whether default risk is fully captured by interest rates charged by banks, or whether highly-leveraged refinance transactions have a higher probability of default. The test is implemented in the regressions presented in Table 6. In Column (1) we present the base regression: we regress the default indicator on refinance indicators interacted with CLTV indicators. The regression shows that the likelihood of default increases with leverage for the refinance loans.

In Column (2), we control for the interest rate charged on the mortgage, as well as interest rate-squared and cubed. The regression shows that the coefficients on the interactions of refinance indicator and leverage indicator become zero or flip signs. With respect to observable leverage ratio, it appears that lenders fully account for default risk.

However, we can improve on the observable leverage ratios by impounding the valuation bias by adjusting the value component of CLTV (as was performed in Section 6). In Columns (3) and (4) we regress borrower default on the dummies of the recalculated CLTV (adjusted for third

\footnotetext{
${ }^{14}$ e.g., these are the main determinants of the interest spread charged to borrowers (Freddie Mac, 2012).
} 
part origination), and controlling for polynomials of the mortgage rate. The results show that mortgage rate accounts for the risk in default for all the leverage groups, except for the very high recalculated leverage group, in which the valuation bias is the largest; for this group the default is unexplained by the interest rates that are charged on the mortgage.

Thus, these results are indicative of interest rates only partly account for the increased default risk due to valuation bias. Of course, this result does not necessarily hold in the timeseries dimension, i.e., the interest rates charged to borrowers do not necessarily compensate lenders for losses incurred in systematic events, like the real-estate bust in 2007-2010.

\section{Robustness}

Our measurement methodology raises several concerns. Primarily, one might be concerned about selection of the first transaction (that could be either a refinance or purchase) or the second transaction (purchase). Another concern is that the quality of the property could change between the first and second transaction in a systematic fashion (e.g., remodeling). In the following section, we discuss and analyze potential biases in our analysis.

\subsection{First Transaction in the Pair (Refinance or Purchase) Is Endogenous}

Our measurement method is based on differencing out properties’ valuations as measured both in prices and in appraisals. One concern is that selection into the sample is correlated with the independent factors that we study here, namely borrower leverage. There are several potential mechanisms that could explain why borrowers at high leverage would condition their refinance (or sale) upon having a high valuation. For example, Genesove and Mayer (1997) find 
that homeowners are reluctant to sell when they are underwater, and Genesove and Mayer (2001) show that homeowners are reluctant to sell when they make a loss on their original investment. ${ }^{15}$

Essentially, these mechanisms link leverage and the likelihood of deal execution through the appreciation of the asset relative to the current valuation. To test whether these mechanisms can explain our results, we condition our regressions on the change in prices between our first transaction in each pair in the data and the transaction preceding it. Thus, we create triplets of transactions, where an additional purchase transaction is added before the current pair of transactions. This additional transaction allows us to control for the change in values prior to the refinance or purchase transaction of interest.

In Table 7, Panel A, Columns (1) to (3), we present base specifications that use the triplet dataset (no controls for pre-transaction returns). Columns (4) to (6) add the log difference in values between the second transaction ( $t=1$; refi or purchase) and the preceding purchase transaction $(t=0)$. Because we require additional prior transactions for the same property, our dataset is reduced to 109,598 observations; there are relatively few observations of transactions with high leverage. We repeat the main specifications from Tables 2 and 3, this time with the sample of triplets.

The results show that controlling for the value appreciation preceding the refinance (or purchase) transaction does not materially affect the results.

\subsection{Second Transaction in the Pair (Purchase) Is Endogenous}

Another concern is that the second transaction in each pair (a purchase transaction) is endogenous. Again, Genesove and Mayer $(1997,2001)$ provide the motivation: homeowners may be reluctant to sell their properties because they are underwater or in loss. Such a selection

\footnotetext{
${ }^{15}$ See also Korteweg and Sorensen (2012) for an estimation of the bias due to selection.
} 
could be correlated with the leverage of borrowers in the previous refinance transaction (the first transaction in the pair).

To provide evidence that our results are independent of this selection issue, we examine a sample of purchase and refinance transactions for which we have value estimation from an automated valuation model (AVM). AVMs are hedonic models that are used by mortgage lenders to estimate valuations of properties. They use information known at the time of the estimation and typically are based on home values of purchase transactions in the vicinity and crude information about homes, such as square-footage, the number of rooms, and the age of the structure. The AVM information that we employ in the study was estimated at the time of each transaction by the originating mortgage lender. By nature, these models have errors that correlate with the quality of the property.

Our test circumvents the selection problem (i.e., the dependence on the second transaction taking place) by focusing on only the first transaction: the refinance transactions. Specifically, we obtain a sample of 441,132 refinance transactions for which we have AVMs as well as human appraiser valuations. Using this sample, we compare human appraisals to the AVM values. Because we do not require any future purchase data, this new sample includes both refinance transactions with future sales and those without. If the effects that we document are driven by selection of the second transaction, then we should not observe these patterns when focusing on only a single transaction.

In Table 7, Panel B, we regress the log difference between appraisals and AVMs on the refinance indicators, interactions with the third-party originator dummy, and interactions with leverage dummies. Column (1) presents the base regression: relative to purchase transactions, the difference in values between human appraisals and AVMs for refinance transactions is 6.9\% 
higher for cash-out refi transactions and 3.7\% higher for rate/term refi transactions. This result is consistent with the previous evidence that appraisals on refinance transactions are inflated, on average (e.g., Table 2, Column (3) shows a valuation bias of 6.8\% for cash-out refis and $4.6 \%$ for rate/term refis).

Furthermore, Column (2) presents evidence that the difference between appraisals and AVMs are especially high for refinance loans that were originated by third-party originators. The magnitude of the effect is $1.7 \%$ for cash-out refis and $2.3 \%$ for rate/term refis. These effects are of a similar magnitude to those documented in Table 4, Panel A (1.7\% for both cash-out refis and rate/term refis).

Finally, Column (3) shows that the valuation bias, measured as the difference between the human appraisal and the AVM, is higher for refi transactions and increases with leverage, peaking at the leverage categories around $85 \%$. Higher leverage ratios show relatively lower valuation bias, which means that the valuation bias (captured in the coefficients of the regression) is not monotonic in leverage. One explanation for this effect is that the difference between human appraisals and AVMs is correlated with differences in house quality. Homes owned by financially constrained borrowers are likely to be more run down than those owned by unconstrained borrowers. The AVM, however, does not observe the quality of the home, and uses geographical information to assess the value of these homes. Hence, it may overestimate the value of poorly maintained homes and underestimate the value of high quality homes. Appraisers, on the other hand, include the quality of the home in their appraisals. Therefore, AVMs would overestimate the value for highly leveraged transactions (a proxy for poor home quality), making the valuation bias smaller. 


\subsection{Changes in the Quality of the Property over Time}

Another concern about the main specification of the study is that the quality of properties could change in a systematic way over time. For example, if borrowers remodel their properties before refinance transactions but not before selling the properties, then we might expect valuations in refinance transactions to be higher than prices in arm's length transactions.

The test in Table 7, Panel B, also addresses this concern. The results show that there is a systematic difference in the valuation levels between appraised values and AVMs for the same property at the same time.

\section{$9 \quad$ Discussion and Conclusion}

The valuation of collateral is often subject to pressures from borrowers-pressures that increase with the financial constraints of the borrower. In this paper, we present evidence from the residential real estate market that these pressures result in substantial overvaluation of assets. We show that valuations of refinance transactions performed by human appraisers are biased upward on average. The bias is more severe when the parties involved (borrowers, intermediaries, and lenders) have a stronger incentive to inflate valuations: e.g., valuations are inflated in highly leveraged transactions and among third-party originations (when mortgages are more likely to be sold to third parties).

The biases identified in the paper have important implications for loan pricing and default models. The inflation of the collateral value that we detect implies that the leverage calculated based on the observed valuation of the asset is downward-biased, creating a systematic bias in standard default models. These models could be improved by correcting the leverage to account 
for the bias in valuation. We find that lenders account for the bias in valuation and charge higher interest rates so that properties that are over-appraised pay higher interest rates.

Our evidence highlights a puzzle in the lending process. Financially constrained borrowers apply pressure to increase borrowing amounts. However, lenders appear to understand this mechanism and adjust mortgage rates accordingly so that they reflect the bias in valuation and at least partly account for the higher likelihood of default of loans supported by inflated collateralized assets. Why are lenders and brokers willing to exert pressure on appraisers instead of simply lending larger amounts to borrowers outright? We offer two explanations for this phenomenon. First, both borrowers and lenders are constrained by lending rules that are imposed by the secondary market and by legislation. In particular, there is almost no lending beyond $100 \%$ of the loan-to-value ratio in the United States. ${ }^{16}$ Inflating valuations allows both borrowers and lenders to informally collude and circumvent the rigid rules imposed by investors in the secondary market and by the government. The second explanation is based on heterogeneity in the population of borrowers. For many borrowers, the financial constraints would not be completely relaxed even if lending rules were more lax, meaning that there will always be an incentive to inflate valuations. Therefore, no matter what bounds investors and lenders put on leverage, collateral will always be inflated by financially constrained borrowers, and lenders will respond optimally.

The biases in the valuation process could potentially be resolved by properly designing institutions and processes. In March 2010, the Government-Sponsored Enterprises (GSEs) began requiring that appraisals of residential properties be ordered by appraisal management companies, not directly by loan officers. Unfortunately, because our methodology requires two

\footnotetext{
${ }^{16}$ Interestingly, in some countries (e.g., Commonwealth countries: the U.K., New Zealand, Australia) lenders allow leverage higher than $100 \%$ at the time of origination of residential mortgages.
} 
consecutive transactions on each property, it cannot effectively test yet whether the valuation bias was indeed eliminated following this change in process.

Although our data and results come from the residential real estate market, our findings have general implications for corporate finance. We chose to study the residential housing market because it allows us to empirically estimate the valuation bias: it is liquid enough to have sufficient transactions for a quantitative study, and at the same time, appraisers have enough latitude to inflate valuations. In other areas of finance, the assessment of value is often done in domains where assets are even more complex (e.g., firms, securities), and thus it is hard to pin down a systematic bias. Nevertheless, such bias is likely to exist given that the experts valuing the assets are subject to pressures by the parties involved in the transactions. 


\section{Appendix A. Variable Definition}

\begin{tabular}{|c|c|}
\hline Variable & Definition \\
\hline Appraised value & The value of a house as was determined by a human appraiser. \\
\hline AVM & The value of a house as was determined by an automated valuation model. \\
\hline Sales price & The price of a house as was recorded in a purchase transaction. \\
\hline Cash-out refi & $\begin{array}{l}\text { An indicator as to whether a transaction is a cash-out refi transaction (loan balance } \\
\text { increases by more than a certain percentage). }\end{array}$ \\
\hline Rate/term refi & $\begin{array}{l}\text { An indicator as to whether a transaction is a rate/term refi transaction (loan balance } \\
\text { does not increase except for closing costs). }\end{array}$ \\
\hline Originated by third party & An indicator as to whether the loan was originated by a broker or correspondent bank. \\
\hline $\begin{array}{l}\text { 3-month local market } \\
\text { returns }\end{array}$ & $\begin{array}{l}\text { Change in the Case-Shiller (1990) house-price index over the previous quarter. } \\
\text { Variable available for the top } 20 \text { MSAs. }\end{array}$ \\
\hline $\mathrm{X} \%<\mathrm{CLTV} \leq \mathrm{Y} \%$ & $\begin{array}{l}\text { An indicator that the combined loan-to-value ratio of the loan is greater than } \mathrm{X} \% \text { and } \\
\text { less than or equal to } \mathrm{Y} \% \text {. }\end{array}$ \\
\hline CLTV & The combined loan-to-value ratio of the mortgage, ranging from 1 to 100. \\
\hline $\begin{array}{l}\text { Defaulted within } 12 \\
\text { months }\end{array}$ & $\begin{array}{l}\text { An indicator that the second transaction in the pair of transactions defaulted (90+ days } \\
\text { past due) within a year. }\end{array}$ \\
\hline Serious delinquency & $\begin{array}{l}\text { An indicator as to whether the second transaction in the pair of transactions considered } \\
\text { had a serious delinquency ( } 60+\text { days past due). }\end{array}$ \\
\hline $\begin{array}{l}\text { FICO / } 100 \text { (at } \\
\text { origination) }\end{array}$ & FICO credit score at the origination of the mortgage. (Variable is divided by 100.) \\
\hline Short-term ARM indicator & $\begin{array}{l}\text { An indicator as to whether the mortgage is a short-term (teaser period }<=3 \text { years) } \\
\text { adjustable rate mortgage (ARM). }\end{array}$ \\
\hline Hybrid ARM indicator & $\begin{array}{l}\text { An indicator as to whether the mortgage is a hybrid adjustable rate mortgage (ARM). } \\
\text { Teaser period can be } 5,7 \text {, or } 10 \text { years and rate resets every year after the teaser period. }\end{array}$ \\
\hline $\begin{array}{l}\text { Fixed rate 15-year (or 30- } \\
\text { year) mortgage }\end{array}$ & An indicator as to whether the mortgage is a 15 -year (or 30-year) fixed rate mortgage. \\
\hline Excess premium & The residual of a regression of the mortgage rate on mortgage characteristics. \\
\hline Owner-occupier indicator & An indicator as to whether the property is owned by an owner-occupier. \\
\hline Debt-to-income ratio & $\begin{array}{l}\text { Back end ratio: a ratio of the monthly housing expense plus other debt payments } \\
\text { divided by monthly income. }\end{array}$ \\
\hline Condo indicator & $\begin{array}{l}\text { An indicator as to whether the property is a condo (as opposed to a single- or multi- } \\
\text { family home). }\end{array}$ \\
\hline House-price index growth & Quarter-on-quarter house price growth in the Case-Shiller index for the MSA. \\
\hline Valuation bias & $\begin{array}{l}\text { The average appraisal in the MSA-quarter as estimated from an MSA quarter-level } \\
\text { regression. }\end{array}$ \\
\hline Tenure & $\begin{array}{l}\text { The time lapsed (measured in months) from the first transaction to the second } \\
\text { transaction. }\end{array}$ \\
\hline Lender fixed effect ( $\mathrm{t}-1)$ & $\begin{array}{l}\text { Measures the historical overvaluation at the lender level. The variable is calculated as } \\
\text { follows. We split the data by years, and run a regression of } \log (\text { Value }(t=1) / \\
\text { Price }(t=2)) \text { with the usual controls and interactions of the refi indicator with lender } \\
\text { fixed effects. For each year, we sort the interaction of the refi indicator and the lender } \\
\text { fixed effects into ten bins and scale to a range of } 0 \text { to } 1 \text {. High lender fixed effect }(=1) \\
\text { means that the lender was in the top decile of appraisal overvaluation in the previous } \\
\text { year. }\end{array}$ \\
\hline HHI & $\begin{array}{l}\text { Herfindahl-Hirschman Index. Measures the concentration of lenders at the MSA-year } \\
\text { level. The index is computed as the sum of squared market share of each lender. }\end{array}$ \\
\hline
\end{tabular}




\section{References}

Agarwal, Sumit, Gene Amromin, Itzhak Ben-David, Souphala Chomsisengphet, and Douglas Evanoff, 2011, The role of securitization in mortgage renegotiation, Journal of Financial Economics 102(3), 559-578.

Agarwal, Sumit, Gene Amromin, Itzhak Ben-David, Souphala Chomsisengphet, and Douglas Evanoff, 2013, Predatory Lending and the Subprime Crisis, Journal of Financial Economics, forthcoming.

Agarwal, Sumit and Itzhak Ben-David, 2012, Do loan officers' incentives lead to lax lending standards? Working Paper, The Ohio State University.

Agarwal, Sumit, Yan Chang, and Abdullah Yavas, 2012, Adverse selection in mortgage securitization, Journal of Financial Economics 105 (3), 640-660.

Aghion, Philippe, and Patrick Bolton, 1992, An incomplete contracts approach to financial contracting, Review of Economic Studies 59(3), 473-494.

Allen, Linda, Julapa Jagtiani, Stavros Peristiani, and Anthony Saunders, 2004, The role of bank advisors in mergers and acquisitions, Journal of Money, Credit, and Banking 36(2), 197-224.

Ambrose, Brent W., and Charles A. Capone, 1998, Modeling the conditional probability of foreclosure in the context of single-family mortgage default resolutions, Real Estate Economics 26(3), 391-429.

Ben-David, Itzhak, 2011, Financial constraints and inflated home prices during the real-estate boom, American Economic Journal: Applied Economics 3(3), 55-78.

Benmelech, Efraim, and Nittai Bergman, 2009, Collateral pricing, Journal of Financial Economics 91, 339-360.

Benmelech, Efraim, Mark J. Garmaise, and Tobias J. Moskowitz, 2005, Do liquidation values affect financial contracts? Evidence from commercial loan contracts and zoning regulation, Quarterly Journal of Economics 120(3), 1121-1154.

Berger, Allen., Marco A. Espinosa-Vega, W. Scott Frame, and Nathan H. Miller, 2011, Why Do Borrowers Pledge Collateral? New Empirical Evidence on the Role of Asymmetric Information, Journal of Financial Intermediation 20, 55-70.

Berger, Allen N., Gregory F. Udell, 1990, Collateral, loan quality and bank risk, Journal of Monetary Economics 25(1), 21-42.

Bolton, Patrick, Xavier Freixas, and Joel Shapiro, 2007, Conflicts of interest, information provision, and competition in the financial services industry, Journal of Financial Economics 85(2), 297-330.

Campbell, John Y., Stefano Giglio, and Parag Pathak, 2011, Forced sales and house prices, American Economic Review 101, 2108-2131.

Case, Karl E., and Robert J. Shiller, 1990, Forecasting prices and excess returns in the housing market, Real Estate Economics 18(3), 253-273.

Chan, Yuk-Shee, and Anjan V. Thakor, 1987, Collateral and competitive equilibria with moral hazard and private information, Journal of Finance 42, 345-363.

Cho, Man, and Isaac F. Megbolugbe, 1996, An empirical analysis of property appraisal and mortgage redlining, Journal of Real Estate Finance and Economics 13, 45-55.

Deng, Yongheng, John Quigley and Robert Van Order, 2000, Mortgage terminations, heterogeneity and the exercise of mortgage options, Econometrica 68(2), 275-307. 
Elul, Ronel, Nicholas S. Souleles, Souphala Chomsisengphet, Dennis Glennon, and Robert Hunt, 2010, What "triggers" mortgage default?, American Economic Review: Papers \& Proceedings 100, 490494.

Fannie Mae, 2012, Fannie Mae appraisal messaging notification, https://www.fanniemae.com /content/news/appraisal-messaging-notification.pdf, accessed on December 12, 2012.

Federal Reserve, Press Release on October 18, 2010, http://www.federalreserve.gov/newsevents/press /bcreg/20101018a.htm, accessed on Dec 12, 2012.

Freddie Mac, Postsettlement delivery fee, www.freddiemac.com/singlefamily/pdf/ex19.pdf, accessed on June 28, 2012.

Garmiase, Mark J., 2012, Borrower misrepresentation and loan performance, Working paper, University of California, Los Angeles.

Genesove, David, and Christopher J. Mayer, 1997, Equity and time to sale in the real estate market, American Economic Review 87(3), 255-269.

Genesove, David, and Christopher Mayer, 2001, Loss aversion and seller behavior: Evidence from the housing market, Quarterly Journal of Economics 116(4), 1233-1260.

Gorton, Gary, and George Pennacchi, 1995, Banks and loan sales: Marketing non-marketable assets, Journal of Monetary Economics 35(3), 389-411.

Greenspan, Alan, and James Kennedy, 2008, Sources and uses of equity extracted from homes, Oxford Review of Economic Policy 24, 120-144.

Harding, John P., Eric Rosenblatt, and Vincent Yao, 2009, the contagion of the foreclosed properties, Journal of Urban Economics 66 (3), 164-178.

Harding, John P., Eric Rosenblatt, and Vincent Yao, 2012, The foreclosure discount: myth or reality? Journal of Urban Economics 71, 204-218.

Hart, Oliver, 1995, Firms, Contracts, and Financial Structure, Oxford University Press, Oxford.

Hart, Oliver, and John Moore, 1994, A theory of debt based on the inalienability of human capital, Quarterly Journal of Economics 109, 841-879.

Hart, Oliver, and John Moore, 1998, Default and renegotiation: A dynamic model of debt, Quarterly Journal of Economics 113, 1-41.

Haughwout, Andrew F., Donghoon Lee, Joseph Tracy, and Wilbert van de Klaauw, 2011, Real estate investors, the leverage cycle, and the housing market crisis, Working paper, Federal Reserve Bank of New York.

Holmstrom, Bengt, and Jean Tirole, 1997, Financial intermediation, loanable funds, and the real sector, Quarterly Journal of Economics 62, 663-691.

Inderst, Roman, and Holger M. Mueller, 2007, A lender-based theory of collateral, Journal of Financial Economics 84(3), 826-859.

Jiang, Wei, Ashlyn Aiko Nelson, and Edward Vytlacil, 2009, Liars loan? Effects of origination channel and information falsification on mortgage delinquency, Working paper, Columbia University.

Johnson, Herb, and René M. Stulz, 1985, An analysis of secured debt, Journal of Financial Economics 14, 501-522.

Kelly, Austin, 2007, Appraisals, automated valuation models, and mortgage default, Working paper, Federal Housing Finance Agency. 
Keys, Benjamin J., Tanmoy K. Mukherjee, Amit Seru, and Vikrant Vig, 2010, Did securitization lead to lax screening? Evidence from subprime loans, Quarterly Journal of Economics 125, 307-362.

Korteweg, Arthur, and Morten Sorensen, 2012, Estimating loan-to-value and foreclosure behavior, Working paper, Stanford University.

Lacour-Little, Michael, and Stephen Malpezzi, 2003, Appraisal quality and residential mortgage default: evidence from Alaska, Journal of Real Estate Finance and Economics 27(2), 211-233.

Mayer, Christopher, Karen Pence, and Shane Sherlund, 2009, The rise in mortgage defaults, Journal of Economic Perspectives 23(1), 27-50.

Mian, Atif, and Amir Sufi, 2010, Household leverage and the recession of 2007 to 2009, IMF Economic Review 58(1), 74-117.

Michaely, Roni, and Kenneth Womack, 1999, Conflict of interest and the credibility of underwriter analyst recommendations, Review of Financial Studies 12(4), 653-686.

Pennacchi, George, 1988, Loan sales and the cost of bank capital, Journal of Finance 43(2), 375-396.

Petersen, Mitchell A., 2004, Information: Hard and soft, Working paper, Northwestern University.

Piskorski, Tomasz, Amit Seru, and Vikrant Vig, 2010, Securitization and distressed loan renegotiation: evidence from the subprime mortgage crisis, Journal of Financial Economics 97(3), 369-397.

Piskorski, Tomasz, Amit Seru, and James Witkin, 2013, Asset Quality Misrepresentation by Financial Intermediaries: Evidence from RMBS Market, Working Paper, University of Chicago.

Rajan, Uday, Amit, Seru, and Vikrant Vig, 2013, The failure of models that predict failure: Distance, incentives and default, Journal of Financial Economics, forthcoming.

Tirole, Jean, 2005, The Theory of Corporate Finance, Princeton University Press, Princeton, NJ.

Vig, Vikrant, 2013, Access to collateral and corporate debt structure: Evidence from a natural experiment, Journal of Finance 68(3), 881-928.

White, Lawrence J., 2010, The credit rating agencies, Journal of Economic Perspectives 24(2), 211-226.

Zingales, Luigi, 2012, A capitalism for the people: Recapturing the lost genius of American prosperity, Basic Books: New York. 


\section{Table 1. Summary Statistics}

The table presents summary statistics for the data used in the study.

\begin{tabular}{|c|c|c|c|c|c|c|c|c|}
\hline Variable & $\mathrm{N}$ & Mean & Std dev & Min & Q25 & Q50 & Q75 & $\operatorname{Max}$ \\
\hline Prior sale price or appraised value $(t=1)$ & $1,011,749$ & 216,913 & 123,333 & 9,000 & 130,000 & 185,000 & 273,913 & $1,000,000$ \\
\hline Sale price $(t=2)$ & $1,011,749$ & 240,879 & 141,850 & 9,000 & 140,000 & 205,000 & 304,000 & $1,000,000$ \\
\hline $\log ($ Value $(t=1) /$ Price $(t=2)) \times 100$ & $1,011,749$ & 9.418 & 29.867 & -110.29 & -1.73 & 10.71 & 26.30 & 85.02 \\
\hline Cash-out refi & $1,011,749$ & 0.250 & 0.433 & 0.00 & 0.00 & 0.00 & 1.00 & 1.00 \\
\hline Rate refi & $1,011,749$ & 0.339 & 0.474 & 0.00 & 0.00 & 0.00 & 1.00 & 1.00 \\
\hline Originated by third party & $1,011,749$ & 0.516 & 0.500 & 0.00 & 0.00 & 1.00 & 1.00 & 1.00 \\
\hline 3-month local market returns & 431,580 & 0.022 & 0.031 & -0.15 & 0.01 & 0.02 & 0.04 & 0.22 \\
\hline CLTV $\leq 70 \%$ & $1,011,749$ & 0.298 & 0.457 & 0.00 & 0.00 & 0.00 & 1.00 & 1.00 \\
\hline $70 \%<$ CLTV $<80 \%$ & $1,011,749$ & 0.194 & 0.396 & 0.00 & 0.00 & 0.00 & 0.00 & 1.00 \\
\hline CLTV $=80$ & $1,011,749$ & 0.184 & 0.388 & 0.00 & 0.00 & 0.00 & 0.00 & 1.00 \\
\hline $80 \%<$ CLTV $\leq 85 \%$ & $1,011,749$ & 0.035 & 0.184 & 0.00 & 0.00 & 0.00 & 0.00 & 1.00 \\
\hline $85 \%<\mathrm{CLTV} \leq 90 \%$ & $1,011,749$ & 0.114 & 0.318 & 0.00 & 0.00 & 0.00 & 0.00 & 1.00 \\
\hline $90 \%<$ CLTV $\leq 95$ & $1,011,749$ & 0.105 & 0.307 & 0.00 & 0.00 & 0.00 & 0.00 & 1.00 \\
\hline $95 \%<$ CLTV & $1,011,749$ & 0.069 & 0.254 & 0.00 & 0.00 & 0.00 & 0.00 & 1.00 \\
\hline Defaulted & $1,011,749$ & 0.121 & 0.326 & 0.00 & 0.00 & 0.00 & 0.00 & 1.00 \\
\hline Serious delinquency & $1,011,749$ & 0.144 & 0.351 & 0.00 & 0.00 & 0.00 & 0.00 & 1.00 \\
\hline FICO / 100 (at origination) & $1,011,749$ & 7.146 & 0.576 & 3.00 & 6.76 & 7.21 & 7.61 & 8.99 \\
\hline Combined LTV (CLTV) & $1,011,749$ & 0.758 & 0.167 & 0.03 & 0.68 & 0.80 & 0.90 & 1.00 \\
\hline Short-term ARM indicator & $1,011,749$ & 0.034 & 0.181 & 0.00 & 0.00 & 0.00 & 0.00 & 1.00 \\
\hline Hybrid ARM indicator & $1,011,749$ & 0.089 & 0.284 & 0.00 & 0.00 & 0.00 & 0.00 & 1.00 \\
\hline Fixed rate 15 -year mortgage & $1,011,749$ & 0.187 & 0.390 & 0.00 & 0.00 & 0.00 & 0.00 & 1.00 \\
\hline Fixed rate 30 -year mortgage & $1,011,749$ & 0.690 & 0.462 & 0.00 & 0.00 & 1.00 & 1.00 & 1.00 \\
\hline Excess premium & $1,011,749$ & -0.009 & 0.749 & -4.03 & -0.51 & -0.04 & 0.42 & 7.83 \\
\hline Owner-occupier indicator & $1,011,749$ & 0.945 & 0.228 & 0.00 & 1.00 & 1.00 & 1.00 & 1.00 \\
\hline Debt-to-income ratio & $1,011,749$ & 0.344 & 0.136 & 0.00 & 0.25 & 0.34 & 0.42 & 1.00 \\
\hline HHI lenders & 397,596 & 3.466 & 1.686 & 1.30 & 2.27 & 2.97 & 4.14 & 20.55 \\
\hline Condo indicator & $1,011,749$ & 0.042 & 0.201 & 0.00 & 0.00 & 0.00 & 0.00 & 1.00 \\
\hline Size (sqft '000) & 916,884 & 1.813 & 0.896 & 0.14 & 1.30 & 1.68 & 2.19 & 156.77 \\
\hline Tenure (months) & $1,008,700$ & 35.894 & 25.883 & 1.00 & 16.00 & 28.00 & 51.00 & 381.00 \\
\hline
\end{tabular}




\section{Table 2. Estimating the Average Valuation Bias in Refinance Transactions}

The table explores the valuation bias among cash-out and rate/term refi transactions. Sample observations are based on pairs of transactions on the same property, and the dependent variable measures the difference in appraised value for the second minus the first transaction. Defaulted and serious delinquency are dummies indicating whether the second transaction in the pair defaulted (90+ days past due) or was in serious delinquency (60+ days past due), respectively. Cash-out refi and Rate/term refi indicators describe the first transaction in each pair. Mortgage controls include information about the first transaction: FICO credit score (at origination), combined loan-to-value ratio (CLTV), short-term ARM indicator, hybrid ARM indicator, fixed rate 15-year mortgage indicator, fixed rate 30-year mortgage indicator, excess premium indicator, owner-occupier indicator, debt-to-income ratio, condo indicator, property size, property age, and tenure. MSA $\times$ YYQQ FE is MSA-quarter fixed effects. There are MSA-quarter fixed effects for the first transaction in each pair as well as for the second transaction. Variable definitions are in Appendix A. All regressions are OLS regressions. Standard errors are clustered at the calendar quarter level. $t$ statistics are reported in parentheses. ${ }^{* * *}, * *$, and $*$ denote statistical significance at the $1 \%, 5 \%$, and $10 \%$ levels, respectively.

\begin{tabular}{|c|c|c|c|c|}
\hline \multirow{2}{*}{ Dependent variable: } & \multicolumn{4}{|c|}{$\log ($ Value $(t=1) /$ Price $(t=2)) \times 100$} \\
\hline & (1) & (2) & (3) & (4) \\
\hline \multirow[t]{2}{*}{ 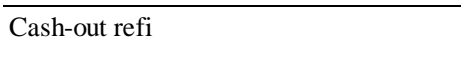 } & $4.84^{* * *}$ & $4.93 * * *$ & $6.76^{* * *}$ & $7.05^{* * *}$ \\
\hline & $(52.57)$ & $(54.90)$ & $(95.01)$ & (94.96) \\
\hline \multirow[t]{2}{*}{ Rate/term refi } & $1.90^{* * *}$ & $2.75^{* * *}$ & $4.55^{* * *}$ & $4.55^{* * *}$ \\
\hline & $(27.50)$ & $(37.77)$ & $(70.64)$ & $(67.20)$ \\
\hline \multirow{2}{*}{ Defaulted } & $25.60 * * *$ & $24.53 * * *$ & $29.05 * * *$ & $29.29 * * *$ \\
\hline & (78.73) & $(77.03)$ & $(119.21)$ & $(114.89)$ \\
\hline \multirow[t]{2}{*}{ Serious delinquency } & 0.27 & $4.83^{* * *}$ & $5.31^{* * *}$ & $5.58^{* * *}$ \\
\hline & $(1.71)$ & $(31.46)$ & (33.53) & (33.23) \\
\hline \multirow[t]{2}{*}{ FICO (at origination) } & & $1.11^{* * *}$ & $0.35^{* * *}$ & $0.27 * * *$ \\
\hline & & $(20.36)$ & $(7.54)$ & $(5.61)$ \\
\hline \multirow[t]{2}{*}{ CLTV } & & $-4.34 * * *$ & $-5.08 * * *$ & $-5.06^{* * *}$ \\
\hline & & $(-21.40)$ & $(-29.30)$ & $(-26.97)$ \\
\hline \multirow[t]{2}{*}{ Short-term ARM indicator } & & $0.87^{* * *}$ & $2.06 * * *$ & $2.10^{* * *}$ \\
\hline & & $(6.92)$ & $(17.86)$ & -17.16 \\
\hline \multirow[t]{2}{*}{ Hybrid ARM indicator } & & $2.03^{* * *}$ & $2.54^{* * *}$ & $2.49 * * *$ \\
\hline & & $(17.26)$ & (30.58) & -28.81 \\
\hline \multirow[t]{2}{*}{ Fixed rate 15 -year mortgage } & & $-3.15^{* * *}$ & $-3.38 * * *$ & $-3.36^{* * *}$ \\
\hline & & $(-44.67)$ & $(-53.04)$ & $(-49.45)$ \\
\hline \multirow{2}{*}{ Fixed rate 30-year mortgage } & & $3.38 * * *$ & $2.32 * * *$ & $2.42 * * *$ \\
\hline & & $(25.41)$ & (26.35) & -26.47 \\
\hline \multirow[t]{2}{*}{ Excess premium } & & $-1.49 * * *$ & $-1.88^{* * * *}$ & $-1.85^{* * *}$ \\
\hline & & $(-34.08)$ & $(-41.73)$ & $(-38.98)$ \\
\hline \multirow[t]{2}{*}{ Owner-occupier indicator } & & $0.85^{* * *}$ & $1.70^{* * *}$ & $1.27 * * *$ \\
\hline & & $(6.96)$ & (13.93) & -10.13 \\
\hline \multirow[t]{2}{*}{ Debt-to-income ratio } & & $5.21^{* * *}$ & $4.24^{* * *}$ & $4.10^{* * *}$ \\
\hline & & $(28.92)$ & $(25.60)$ & -23.42 \\
\hline \multirow[t]{2}{*}{ Condo indicator } & & $1.52 * * *$ & $2.29 * * *$ & $1.58 * * *$ \\
\hline & & $(6.44)$ & $(17.66)$ & (11.17) \\
\hline \multirow[t]{2}{*}{ Tenure } & & $-0.13^{* * *}$ & $-0.25 * * *$ & $-0.25 * * *$ \\
\hline & & $(-119.69)$ & $(-143.31)$ & $(-135.91)$ \\
\hline \multirow[t]{2}{*}{ Size (sqft '000) } & & & & $-0.15^{* *}$ \\
\hline & & & & $(-2.83)$ \\
\hline \multirow[t]{2}{*}{ Property age (years) } & & & & $-0.06^{* * *}$ \\
\hline & & & & $(-31.82)$ \\
\hline MSA $\times$ YYQQ (first transaction) FE & No & No & Yes & Yes \\
\hline MSA $\times$ YYQQ (second transaction) FE & No & No & Yes & Yes \\
\hline Observations & $1,011,749$ & $1,011,749$ & $1,011,749$ & 927,588 \\
\hline Adj $R^{2}$ & 0.105 & 0.155 & 0.323 & 0.327 \\
\hline
\end{tabular}




\section{Table 3. Valuation Bias and Borrower Leverage}

The table explores the valuation bias with respect to borrower leverage. Sample observations are based on pairs of transactions on the same property, and the dependent variable measures the difference in appraised value for the second minus the first transaction. Defaulted and serious delinquency are dummies indicating whether the second transaction in the pair defaulted (90+ days past due) or was in serious delinquency (60+ days past due), respectively. Cash-out refi and Rate/term refi indicators describe the first transaction in each pair. In Columns (4) and (5) the sample is split to recourse and non-recourse mortgages. In Columns (6) and (7) the sample is split to mortgages with low- and full documentation. Mortgage controls include information about the first transaction: FICO credit score (at origination), combined loan-to-value ratio (CLTV), short-term ARM indicator, hybrid ARM indicator, fixed rate 15-year mortgage indicator, fixed rate 30-year mortgage indicator, excess premium indicator, owner-occupier indicator, debt-to-income ratio, condo indicator, property size, property age, and tenure. MSA $\times$ YYQQ FE is MSAquarter fixed effects. There are MSA-quarter fixed effects for the first transaction in each pair as well as for the second transaction. Variable definitions are in Appendix A. All regressions are OLS regressions. Standard errors are clustered at the calendar quarter level. $t$-statistics are reported in parentheses. ${ }^{* * *},{ }^{* *}$, and ${ }^{*}$ denote statistical significance at the $1 \%, 5 \%$, and $10 \%$ levels, respectively.

\begin{tabular}{|c|c|c|c|c|c|c|c|}
\hline \multirow{3}{*}{$\begin{array}{r}\text { Dependent variable: } \\
\text { Sample: }\end{array}$} & \multicolumn{7}{|c|}{$\log ($ Value $(t=1) /$ Price $(t=2)) \times 100$} \\
\hline & All & All & All & Recourse & Non-recourse & Low Doc & Full Doc \\
\hline & (1) & (2) & (3) & (4) & (5) & (6) & (7) \\
\hline \multicolumn{8}{|l|}{ Cash-out refi } \\
\hline$\times \mathrm{CLTV} \leq 70 \%$ & $\begin{array}{l}3.74 * * * \\
(29.59)\end{array}$ & $\begin{array}{l}3.71^{* * *} \\
(30.12)\end{array}$ & $\begin{array}{c}4.72^{* * *} \\
(41.18)\end{array}$ & $\begin{array}{l}4.68^{* * *} \\
(34.36)\end{array}$ & $\begin{array}{l}4.85^{* * *} \\
(23.15)\end{array}$ & $\begin{array}{l}7.48^{* * *} \\
(23.94)\end{array}$ & $\begin{array}{l}5.10^{* * *} \\
(51.52)\end{array}$ \\
\hline$\times 70 \%<\mathrm{CLTV}<80 \%$ & $\begin{array}{l}3.49^{* * *} \\
(26.24)\end{array}$ & $\begin{array}{l}3.53^{* * *} \\
(24.77)\end{array}$ & $\begin{array}{l}5.15^{* * *} \\
(37.43)\end{array}$ & $\begin{array}{l}5.03^{* * *} \\
(30.69)\end{array}$ & $\begin{array}{l}5.44^{* * *} \\
(21.71)\end{array}$ & $\begin{array}{l}9.09 * * * \\
(23.72)\end{array}$ & $\begin{array}{l}6.27^{* * *} \\
(62.75)\end{array}$ \\
\hline$\times \mathrm{CLTV}=80 \%$ & $\begin{array}{l}5.06 * * * \\
(31.98)\end{array}$ & $\begin{array}{l}4.56^{* * *} \\
(26.22)\end{array}$ & $\begin{array}{l}6.32^{* * *} \\
(39.21)\end{array}$ & $\begin{array}{l}6.04^{* * *} \\
(30.74)\end{array}$ & $\begin{array}{l}6.94 * * * \\
(24.79)\end{array}$ & $\begin{array}{l}9.77^{* * *} \\
(21.41)\end{array}$ & $\begin{array}{l}7.63^{* * *} \\
(61.59)\end{array}$ \\
\hline$\times 80 \%<\mathrm{CLTV} \leq 85 \%$ & $\begin{array}{l}4.96 * * * \\
(18.20)\end{array}$ & $\begin{array}{l}4.79 * * * \\
(16.95)\end{array}$ & $\begin{array}{l}6.53^{* * *} \\
(24.61)\end{array}$ & $\begin{array}{l}6.20^{* * *} \\
(20.03)\end{array}$ & $\begin{array}{l}7.49 * * * \\
(14.85)\end{array}$ & $\begin{array}{c}10.70^{* * *} \\
(11.21)\end{array}$ & $\begin{array}{l}8.04^{* * *} \\
(32.99)\end{array}$ \\
\hline$\times 85 \%<\mathrm{CLTV} \leq 90 \%$ & $\begin{array}{l}5.29 * * * \\
(25.02)\end{array}$ & $\begin{array}{l}4.58^{* * *} \\
(19.48)\end{array}$ & $\begin{array}{l}6.30^{* * *} \\
(30.01)\end{array}$ & $\begin{array}{l}6.18^{* * *} \\
(24.94)\end{array}$ & $\begin{array}{l}6.63^{* * *} \\
(16.98)\end{array}$ & $\begin{array}{l}9.17 * * * \\
(16.43)\end{array}$ & $\begin{array}{l}8.06^{* * *} \\
(46.81)\end{array}$ \\
\hline$\times 90 \%<\mathrm{CLTV} \leq 95 \%$ & $\begin{array}{c}7.06 * * * \\
(6.99)\end{array}$ & $\begin{array}{c}4.79 * * * \\
(4.81)\end{array}$ & $\begin{array}{c}4.56^{* * *} \\
(6.03)\end{array}$ & $\begin{array}{c}3.53 * * * \\
(3.56)\end{array}$ & $\begin{array}{l}6.36^{* * * *} \\
(5.58)\end{array}$ & $\begin{array}{c}8.64 * * * \\
(8.86)\end{array}$ & $\begin{array}{l}3.28 * * \\
(2.98)\end{array}$ \\
\hline$\times 95 \%<\mathrm{CLTV}$ & $\begin{array}{c}10.44 * * * \\
(5.92)\end{array}$ & $\begin{array}{c}7.17^{* * *} \\
(4.06)\end{array}$ & $\begin{array}{c}5.30^{* * *} \\
(4.56)\end{array}$ & $\begin{array}{l}3.66^{* *} \\
(2.61)\end{array}$ & $\begin{array}{l}8.72 * * * \\
(4.46)\end{array}$ & $\begin{array}{c}9.52 * * * \\
(6.93)\end{array}$ & $\begin{array}{c}-0.89 \\
(-0.42)\end{array}$ \\
\hline \multicolumn{8}{|l|}{ Rate refi } \\
\hline$\times \mathrm{CLTV} \leq 70 \%$ & $\begin{array}{c}0.07 \\
(0.63)\end{array}$ & $\begin{array}{l}1.15^{* * *} \\
(10.25)\end{array}$ & $\begin{array}{l}2.53^{* * *} \\
(22.60)\end{array}$ & $\begin{array}{l}2.53^{* * *} \\
(19.16)\end{array}$ & $\begin{array}{l}2.55^{* * *} \\
(12.38)\end{array}$ & $\begin{array}{c}1.78^{* * *} \\
(5.88)\end{array}$ & $\begin{array}{l}3.05^{* * *} \\
(31.45)\end{array}$ \\
\hline$\times 70 \%<\mathrm{CLTV}<80 \%$ & $\begin{array}{c}1.10^{* * *} \\
(9.52)\end{array}$ & $\begin{array}{l}1.62^{* * *} \\
(12.53)\end{array}$ & $\begin{array}{l}3.11^{* * *} \\
(24.10)\end{array}$ & $\begin{array}{l}3.00 * * * \\
(19.42)\end{array}$ & $\begin{array}{l}3.38 * * * \\
(14.62)\end{array}$ & $\begin{array}{l}3.81^{* * *} \\
(13.89)\end{array}$ & $\begin{array}{l}4.35^{* * *} \\
(50.87)\end{array}$ \\
\hline$\times \mathrm{CLTV}=80 \%$ & $\begin{array}{l}2.39 * * * \\
(17.64)\end{array}$ & $\begin{array}{l}2.50^{* * *} \\
(16.42)\end{array}$ & $\begin{array}{l}4.17^{* * *} \\
(28.00)\end{array}$ & $\begin{array}{c}4.09 * * * \\
(22.66)\end{array}$ & $\begin{array}{l}4.41^{* * *} \\
(16.95)\end{array}$ & $\begin{array}{l}4.64^{* * *} \\
(15.34)\end{array}$ & $\begin{array}{l}5.62 * * * \\
(52.17)\end{array}$ \\
\hline$\times 80 \%<\mathrm{CLTV} \leq 85 \%$ & $\begin{array}{l}2.36 * * * \\
(12.94)\end{array}$ & $\begin{array}{c}2.79 * * * \\
(14.54)\end{array}$ & $\begin{array}{l}3.97^{* * *} \\
(21.05)\end{array}$ & $\begin{array}{l}3.88 * * * \\
(17.26)\end{array}$ & $\begin{array}{l}4.18^{* * * *} \\
(12.21)\end{array}$ & $\begin{array}{l}6.88^{* * *} \\
(11.85)\end{array}$ & $\begin{array}{l}5.49 * * * \\
(35.80)\end{array}$ \\
\hline$\times 85 \%<\mathrm{CLTV} \leq 90 \%$ & $\begin{array}{c}1.47^{* * *} \\
(9.55)\end{array}$ & $\begin{array}{l}1.99 * * * \\
(11.14)\end{array}$ & $\begin{array}{c}2.86^{* * *} \\
(16.53)\end{array}$ & $\begin{array}{l}2.91^{* * * *} \\
(13.95)\end{array}$ & $\begin{array}{c}2.79 * * * \\
(9.17)\end{array}$ & $\begin{array}{l}5.81^{* * *} \\
(15.13)\end{array}$ & $\begin{array}{l}4.60^{* * *} \\
(38.58)\end{array}$ \\
\hline$\times 90 \%<\mathrm{CLTV} \leq 95 \%$ & $\begin{array}{l}2.21^{* * *} \\
(10.86)\end{array}$ & $\begin{array}{c}2.07 * * * \\
(8.93)\end{array}$ & $\begin{array}{l}2.42^{* * *} \\
(11.57)\end{array}$ & $\begin{array}{c}2.48 * * * \\
(9.89)\end{array}$ & $\begin{array}{c}2.34^{* * * *} \\
(6.29)\end{array}$ & $\begin{array}{l}5.85^{* * *} \\
(11.55)\end{array}$ & $\begin{array}{l}4.24 * * * \\
(26.40)\end{array}$ \\
\hline$\times 95 \%<\mathrm{CLTV}$ & $\begin{array}{c}4.90^{* * *} \\
(7.28)\end{array}$ & $\begin{array}{c}3.23^{* * *} \\
(4.78)\end{array}$ & $\begin{array}{l}1.61^{* *} \\
(3.06)\end{array}$ & $\begin{array}{c}1.21 \\
(1.88)\end{array}$ & $\begin{array}{l}2.50^{* *} \\
(2.75)\end{array}$ & $\begin{array}{c}6.41^{* * *} \\
(7.57)\end{array}$ & $\begin{array}{l}1.58^{* *} \\
(2.59)\end{array}$ \\
\hline Defaulted + Serious delinquency indicators & Yes & Yes & Yes & Yes & Yes & Yes & Yes \\
\hline Mortgage controls & No & Yes & Yes & Yes & Yes & Yes & Yes \\
\hline MSA $\times$ YYQQ (first transaction) FE & No & No & Yes & Yes & Yes & Yes & Yes \\
\hline MSA $\times$ YYQQ (second transaction) FE & No & No & Yes & Yes & Yes & Yes & Yes \\
\hline Observations & $1,011,749$ & $1,011,749$ & $1,011,749$ & 673,722 & 338,027 & 94,745 & 917,004 \\
\hline Adj $R^{2}$ & 0.107 & 0.155 & 0.325 & 0.314 & 0.349 & 0.379 & 0.319 \\
\hline
\end{tabular}




\section{Table 4. Determinants of Valuation Bias}

The table explores the determinants of the valuation bias. Sample observations are based on pairs of transactions on the same property, and the dependent variable measures the difference in appraisals for the second minus the first transaction. Panel A explores the correlation of the valuation bias with lender characteristics. Panel B explores the correlation of the magnitude of the valuation bias with the distance from the jumbo-loan cutoff. Panel C explores the magnitude of the valuation above and below leverage thresholds that are correlated with mortgage rate changes. Panel D presents a split of the sample by the year of the first transaction. Defaulted and serious delinquency are dummies indicating whether the second transaction in the pair defaulted (90+ days past due) or was in serious delinquency (60+ days past due), respectively. Cash-out refi and Rate/term refi indicators describe the first transaction in each pair. Mortgage controls include information about the first transaction: FICO credit score (at origination), combined loan-to-value ratio (CLTV), short-term ARM indicator, hybrid ARM indicator, fixed rate 15year mortgage indicator, fixed rate 30-year mortgage indicator, excess premium indicator, owner-occupier indicator, debt-to-income ratio, condo indicator, property size, property age, and tenure. MSA $\times Y Y Q Q F E$ is MSA-quarter fixed effects. There are MSA-quarter fixed effects for the first transaction in each pair as well as for the second transaction. Variable definitions are in Appendix A. All regressions are OLS regressions. Standard errors are clustered at the calendar quarter level. $t$-statistics are reported in parentheses. ${ }^{* * *}, * *$, and ${ }^{*}$ denote statistical significance at the $1 \%, 5 \%$, and $10 \%$ levels, respectively.

\section{Panel A: Lender- and Market-Level Determinants of Valuation Bias}

\begin{tabular}{|c|c|c|c|}
\hline \multirow[t]{2}{*}{ Dependent variable: } & \multicolumn{3}{|c|}{$\log ($ Value $(t=1) /$ Price $(t=2)) \times 100$} \\
\hline & (1) & (2) & (3) \\
\hline \multirow[t]{2}{*}{ Cash-out refi } & $5.64^{* * *}$ & $6.76 * * *$ & $7.04 * * *$ \\
\hline & $(67.00)$ & (88.78) & (76.17) \\
\hline \multirow[t]{2}{*}{$\times$ Third party originator } & $2.00^{* * *}$ & & \\
\hline & (23.63) & & \\
\hline \multirow[t]{2}{*}{$\times$ Lender fixed effect (t-1) } & & $0.15^{* * *}$ & \\
\hline & & $(5.46)$ & \\
\hline \multirow[t]{2}{*}{$\times \mathrm{HHI}$} & & & $0.30 * *$ \\
\hline & & & $(2.97)$ \\
\hline \multirow[t]{2}{*}{ Rate refi } & $3.52^{* * *}$ & $3.17^{* * *}$ & $4.26^{* * *}$ \\
\hline & $(48.36)$ & $(42.20)$ & $(48.14)$ \\
\hline \multirow[t]{2}{*}{$\times$ Third party originator } & $1.99 * * *$ & & \\
\hline & $(28.77)$ & & \\
\hline \multirow[t]{2}{*}{$\times$ Lender fixed effect (t-1) } & & $0.23 * * *$ & \\
\hline & & $(9.00)$ & \\
\hline$\times \mathrm{HHI}$ & & & $0.31 * *$ \\
\hline
\end{tabular}

Third party originator

Lender fixed effect (t-1)

\begin{tabular}{lccc} 
Defaulted + Serious delinquency indicators & Yes & Yes & Yes \\
Mortgage controls & Yes & Yes & Yes \\
MSA × YYQQ (first transaction) FE & Yes & Yes & Yes \\
MSA $\times$ YYQQ (second transaction) FE & Yes & Yes & Yes \\
& & & \\
Observations & $1,011,749$ & 714,892 & 397,596 \\
Adj R $^{2}$ & 0.325 & 0.300 & 0.307 \\
\hline
\end{tabular}

Note: Entire sample restricted to lenders with obs $>=10$ in previous year 
Table 4. Determinants of Valuation Bias (Cont.)

Panel B: Jumbo-Loan Cutoff

\begin{tabular}{|c|c|c|c|c|}
\hline \multirow{3}{*}{$\begin{array}{r}\text { Dependent variable: } \\
\text { Sample restriction (\% of loan limit): }\end{array}$} & \multicolumn{4}{|c|}{$\log ($ Value $(t=1) /$ Price $(t=2)) \times 100$} \\
\hline & $0 \%-85 \%$ & $85 \%-95 \%$ & 95\%-98\% & $98 \%-100 \%$ \\
\hline & (1) & (2) & (3) & (4) \\
\hline \multirow{2}{*}{ 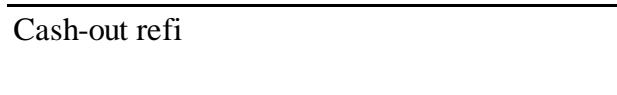 } & $6.90 * * *$ & $5.20 * * *$ & $5.68^{* * *}$ & $4.17^{* * *}$ \\
\hline & (92.06) & (19.68) & (11.25) & (8.66) \\
\hline \multirow[t]{2}{*}{ Rate refi } & $4.77^{* * *}$ & $2.48^{* * *}$ & $2.14^{* * *}$ & 0.64 \\
\hline & $(70.52)$ & $(10.55)$ & $(4.29)$ & (1.39) \\
\hline Defaulted + Serious delinquency indicators & Yes & Yes & Yes & Yes \\
\hline Mortgage controls & Yes & Yes & Yes & Yes \\
\hline MSA $\times$ YYQQ (first transaction) FE & Yes & Yes & Yes & Yes \\
\hline MSA $\times$ YYQQ (second transaction) FE & Yes & Yes & Yes & Yes \\
\hline Observations & 920,388 & 47,796 & 11,282 & 13,142 \\
\hline Adj $R^{2}$ & 0.319 & 0.380 & 0.383 & 0.368 \\
\hline
\end{tabular}

\section{Panel C: Leverage Thresholds}

\begin{tabular}{lccc} 
& $\begin{array}{c}\text { Dependent variable: } \\
\text { Subsample: }\end{array}$ & \multicolumn{3}{c}{$\log ($ Value $(\mathrm{t}=1) /$ Price $(\mathrm{t}=2)) \times 100$} \\
\cline { 2 - 4 } & $84<=$ CLTV $<=86$ & $89<=$ CLTV $<=91$ & $94<=$ CLTV $<=96$ \\
\hline Cash-out refi & $(1)$ & $(2)$ & $(3)$ \\
& $7.14^{* * *}$ & $10.68^{* * *}$ & 5.78 \\
$\times$ & $(7.97)$ & $(4.51)$ & $(1.15)$ \\
Rat or below leverage cutoff & 0.32 & -1.99 & 5.63 \\
& $(0.34)$ & $(-0.84)$ & $(1.11)$ \\
$\times$ At or below leverage cutoff & $3.19^{* * *}$ & $2.70^{* * *}$ & -0.43 \\
& $(4.70)$ & $(3.43)$ & $(-0.22)$ \\
At or below leverage cutoff & $1.59^{*}$ & $2.74^{* * *}$ & $6.53^{* * * *}$ \\
& $(2.19)$ & -3.41 & $(3.31)$ \\
& & & \\
Defaulted + Serious delinquency indicators & 0.55 & -0.07 & $4.26^{* *}$ \\
Mortgage controls & $(1.41)$ & $(-0.10)$ & $(-2.88)$ \\
MSA $\times$ YYQQ (first transaction) FE & & & \\
MSA $\times$ YYQQ (second transaction) FE & Yes & Yes & Yes \\
& Yes & Yes & Yes \\
Observations & Yes & Yes & Yes \\
Adj $\mathrm{R}^{2}$ & Yes & Yes & Yes \\
\hline
\end{tabular}


Table 4. Determinants of Valuation Bias (Cont.)

Panel D: Time-Series of Valuation Bias

\begin{tabular}{|c|c|c|c|c|c|c|c|c|}
\hline \multirow{3}{*}{$\begin{array}{r}\text { Dependent variable } \\
\text { Sample (first transaction) }\end{array}$} & \multicolumn{8}{|c|}{$\log ($ Value $(t=1) /$ Price $(t=2)) \times 100$} \\
\hline & $1990-2000$ & 2001 & 2002 & 2003 & 2004 & 2005 & 2006 & 2007-2011 \\
\hline & (1) & $(2)$ & (3) & (4) & (5) & (6) & (7) & $(8)$ \\
\hline \multirow[t]{2}{*}{ Cash-out refi } & $5.33^{* * *}$ & $8.00 * * *$ & $7.69 * * *$ & $6.85 * * *$ & $5.58 * * *$ & $6.18^{* * *}$ & $8.15^{* * *}$ & $9.32 * * *$ \\
\hline & $(41.06)$ & $(35.70)$ & $(41.47)$ & $(49.44)$ & (29.27) & (29.30) & (33.58) & (52.55) \\
\hline \multirow[t]{2}{*}{ Rate refi } & $3.80^{* * *}$ & $5.99 * * *$ & $6.01^{* * *}$ & $4.44^{* * *}$ & $2.95 * * *$ & $3.90 * * *$ & $6.45^{* * *}$ & $7.45^{* * *}$ \\
\hline & $(34.76)$ & $(27.16)$ & $(33.84)$ & $(34.51)$ & $(16.02)$ & $(17.40)$ & $(23.90)$ & $(44.09)$ \\
\hline Defaulted + Serious delinquency indicators & Yes & Yes & Yes & Yes & Yes & Yes & Yes & Yes \\
\hline Mortgage controls & Yes & Yes & Yes & Yes & Yes & Yes & Yes & Yes \\
\hline MSA $\times$ YYQQ (first transaction) FE & Yes & Yes & Yes & Yes & Yes & Yes & Yes & Yes \\
\hline MSA $\times$ YYQQ (second transaction) FE & Yes & Yes & Yes & Yes & Yes & Yes & Yes & Yes \\
\hline Observations & 273,227 & 86,171 & 125,523 & 213,524 & 87,470 & 70,844 & 55,695 & 99,295 \\
\hline $\operatorname{Adj} R^{2}$ & 0.364 & 0.379 & 0.375 & 0.368 & 0.397 & 0.439 & 0.479 & 0.468 \\
\hline
\end{tabular}




\section{Table 5. Borrower Default and Valuation Bias}

The table explores the relation between the likelihood of borrower default and valuation bias. Columns (1) and (2) present a two-stage analysis. In the first stage (Column (1)), an indicator for default within 12 months is regressed on indicators of observed leverage, controls, and fixed effects. In the second stage (Column (2)), the residuals from the first stage are regressed on indicators of recalculated leverage, which is corrected for valuation bias. The recalculated leverage adjusts the observed leverage by the coefficients of valuation bias with respect to leverage (Table 3, Column (3)) and third-party origination (Table 4, Panel A, Column (1)). Mortgage controls include information about the first transaction: FICO credit score (at origination), combined loan-to-value ratio (CLTV), short-term ARM indicator, hybrid ARM indicator, fixed rate 15-year mortgage indicator, fixed rate 30-year mortgage indicator, excess premium indicator, owner-occupier indicator, debt-to-income ratio, condo indicator, property size, property age, and tenure. MSA $\times$ YYQQ FE is MSA-quarter fixed effects. Variable definitions are in Appendix A. All regressions are OLS regressions. Standard errors are clustered at the calendar quarter level. $t$ statistics are reported in parentheses. ${ }^{* * *}, * *$, and $*$ denote statistical significance at the $1 \%, 5 \%$, and $10 \%$ levels, respectively.

Main test

\begin{tabular}{ccc} 
Dependent variable: & Default indicator $\times 100$ & Residuals \\
\cline { 2 - 3 } & Stage 1 & Stage 2 \\
\hline$(1)$ & $(2)$ \\
\hline
\end{tabular}

Observed CLTV

$70<$ CLTV $<80$

$0.06^{* * *}$

$\mathrm{CLTV}=80$

$0.12 * * *$

$80<$ CLTV $<=85$

$0.16^{* * *}$

$85<$ CLTV $<=90$

$0.23 * * *$

$90<$ CLTV $<=95$

$0.30 * * *$

95 $<$ CLTV $<=100$

(continues on next page) 


\section{Table 5. Borrower Default and Valuation Bias (Cont.)}

(continues from previous page)

\begin{tabular}{|c|c|c|}
\hline \multirow{4}{*}{ Dependent variable: } & \multicolumn{2}{|c|}{ Main test } \\
\hline & \multirow{3}{*}{$\begin{array}{c}\text { Default indicator } \times 100 \\
\text { Stage } 1 \\
(1) \\
\end{array}$} & \multirow{2}{*}{$\begin{array}{c}\text { Residuals } \\
\text { Stage } 2\end{array}$} \\
\hline & & \\
\hline & & $(2)$ \\
\hline \multirow{2}{*}{\multicolumn{3}{|c|}{$\begin{array}{l}\ldots \\
\text { Recalculated CLTV } \\
\end{array}$}} \\
\hline & & \\
\hline \multirow[t]{2}{*}{$70<\mathrm{CLTV}<80$} & & $-0.01 * * *$ \\
\hline & & $(-4.61)$ \\
\hline \multirow[t]{2}{*}{$\mathrm{CLTV}=80$} & & $-0.01 *$ \\
\hline & & $(-2.49)$ \\
\hline \multirow[t]{2}{*}{$80<\mathrm{CLTV}<=85$} & & $-0.02 * * *$ \\
\hline & & $(-8.84)$ \\
\hline \multirow[t]{2}{*}{$85<$ CLTV $<=90$} & & $-0.01 *$ \\
\hline & & $(-2.04)$ \\
\hline \multirow[t]{2}{*}{$90<$ CLTV $<=95$} & & $0.01^{*}$ \\
\hline & & $(2.30)$ \\
\hline \multirow[t]{2}{*}{$95<$ CLTV $<=100$} & & $0.08 * * *$ \\
\hline & & $(15.50)$ \\
\hline \multirow[t]{2}{*}{$100<$ CLTV $<=105$} & & $0.09 * * *$ \\
\hline & & $(8.62)$ \\
\hline \multirow[t]{2}{*}{$105<$ CLTV $<=110$} & & $0.13^{* * *}$ \\
\hline & & $(5.44)$ \\
\hline \multirow[t]{2}{*}{$110<\mathrm{CLTV}$} & & $0.16^{* * *}$ \\
\hline & & $(4.64)$ \\
\hline Other controls & Yes & No \\
\hline MSA $\times$ YYQQ & Yes & No \\
\hline Observations & $1,011,749$ & $1,011,749$ \\
\hline Pseudo-R ${ }^{2}$ & 0.140 & 0.002 \\
\hline
\end{tabular}




\section{Table 6. Is Valuation Bias Priced in Mortgage Interest?}

The table tests whether interest rates charged to mortgages capture the cross-sectional risk of default. Column (1) presents the base regression in which default indicator is regressed on interactions of refinance indicator and leverage indicators, as well as mortgage controls and origination quarter fixed effects. Column (2) includes in addition controls for the interest rate of the mortgage, interest rate squared and interest rate cubed. Columns (3) and (4) use leverage bins based on recalculated leverage (which account for the third-party origination channel). Mortgage controls include information about the first transaction: FICO credit score (at origination), combined loanto-value ratio (CLTV), short-term ARM indicator, hybrid ARM indicator, fixed rate 15-year mortgage indicator, fixed rate 30-year mortgage indicator, excess premium indicator, owner-occupier indicator, debt-to-income ratio, condo indicator, property size, property age, and tenure. MSA $\times$ YYQQ FE is MSA-quarter fixed effects. Variable definitions are in Appendix A. All regressions are OLS regressions. Standard errors are clustered at the calendar quarter level. $t$-statistics are reported in parentheses. ${ }^{* * *}, * *$, and $*$ denote statistical significance at the $1 \%, 5 \%$, and $10 \%$ levels, respectively. 


\section{Table 6. Is Valuation Bias Priced in Mortgage Interest? (Cont.)}

\begin{tabular}{|c|c|c|c|c|}
\hline \multirow{4}{*}{$\begin{array}{r}\text { Dependent variable: } \\
\text { Sample: } \\
\text { Leverage indicators: }\end{array}$} & \multicolumn{4}{|c|}{ Default indicator $\times 100$} \\
\hline & All & All & All & All \\
\hline & \multicolumn{2}{|c|}{ Original } & \multicolumn{2}{|c|}{ Recalculated } \\
\hline & $(1)$ & $(2)$ & (3) & (4) \\
\hline \multicolumn{5}{|l|}{ Cash-out refi } \\
\hline$\times \mathrm{CLTV} \leq 70 \%$ & $\begin{array}{l}0.06^{* * *} \\
(7.77)\end{array}$ & $\begin{array}{l}-0.08^{* * *} \\
(-10.84)\end{array}$ & $\begin{array}{l}0.07^{* * *} \\
(8.77)\end{array}$ & $\begin{array}{l}-0.08^{* * *} \\
(-9.51)\end{array}$ \\
\hline$\times 70 \%<\mathrm{CLTV}<80 \%$ & $\begin{array}{l}0.02 * * \\
(2.90)\end{array}$ & $\begin{array}{c}-0.10^{* * *} \\
(-16.02)\end{array}$ & $\begin{array}{l}0.02 * * \\
(2.98)\end{array}$ & $\begin{array}{l}-0.10^{* * *} \\
(-14.18)\end{array}$ \\
\hline$\times \mathrm{CLTV}=80 \%$ & $\begin{array}{l}0.03^{* *} \\
(3.24)\end{array}$ & $\begin{array}{c}-0.11^{* * *} \\
(-13.20)\end{array}$ & $\begin{array}{l}0.01 \\
(0.95)\end{array}$ & $\begin{array}{l}-0.12 * * * \\
(-15.56)\end{array}$ \\
\hline$\times 80 \%<$ CLTV $\leq 85 \%$ & $\begin{array}{c}0.08^{* * * *} \\
(6.03)\end{array}$ & $\begin{array}{c}-0.08 * * * \\
(-5.57)\end{array}$ & $\begin{array}{l}0.07 * * * \\
(6.47)\end{array}$ & $\begin{array}{l}-0.08 * * * \\
(-7.52)\end{array}$ \\
\hline$\times 85 \%<\mathrm{CLTV} \leq 90 \%$ & $\begin{array}{c}0.11^{* * *} \\
(11.50)\end{array}$ & $\begin{array}{c}-0.05^{* * *} \\
(-4.87)\end{array}$ & $\begin{array}{l}0.11^{* * *} \\
(9.48)\end{array}$ & $\begin{array}{l}-0.05 * * * \\
(-4.43)\end{array}$ \\
\hline$\times 90 \%<\mathrm{CLTV} \leq 95 \%$ & $\begin{array}{c}0.15^{* * *} \\
(4.04)\end{array}$ & $\begin{array}{c}-0.03 \\
(-0.69)\end{array}$ & $\begin{array}{l}0.14^{* * *} \\
(9.46)\end{array}$ & $\begin{array}{l}-0.04^{*} \\
(-2.32)\end{array}$ \\
\hline$\times 95<\mathrm{CLTV}<=100$ & $\begin{array}{c}0.30 * * * \\
(5.15)\end{array}$ & $\begin{array}{c}0.11 \\
(1.89)\end{array}$ & $\begin{array}{l}0.19 * * * \\
(5.88)\end{array}$ & $\begin{array}{l}-0.01 \\
(-0.37)\end{array}$ \\
\hline$\times 100<$ CLTV $<=105$ & & & $\begin{array}{l}0.15^{* *} \\
(2.60)\end{array}$ & $\begin{array}{l}-0.06 \\
(-1.05)\end{array}$ \\
\hline$\times 105<$ CLTV $<=110$ & & & $\begin{array}{l}0.41^{* * *} \\
(6.18)\end{array}$ & $\begin{array}{l}0.18^{* *} \\
(2.64)\end{array}$ \\
\hline \multicolumn{5}{|l|}{$\times 110<\mathrm{CLTV}$} \\
\hline \multicolumn{5}{|l|}{ Rate refi } \\
\hline$\times \mathrm{CLTV} \leq 70 \%$ & $\begin{array}{c}0.03^{* * *} \\
(3.85)\end{array}$ & $\begin{array}{c}-0.15^{* * *} \\
(-22.00)\end{array}$ & $\begin{array}{l}0.04^{* * *} \\
(5.66)\end{array}$ & $\begin{array}{l}-0.14^{* * *} \\
(-19.17)\end{array}$ \\
\hline$\times 70 \%<\mathrm{CLTV}<80 \%$ & $\begin{array}{c}-0.09 * * * \\
(-16.89)\end{array}$ & $\begin{array}{c}-0.23^{* * *} \\
(-40.15)\end{array}$ & $\begin{array}{l}-0.08^{* * *} \\
(-13.15)\end{array}$ & $\begin{array}{l}-0.22 * * * \\
(-34.96)\end{array}$ \\
\hline$\times \mathrm{CLTV}=80 \%$ & $\begin{array}{c}-0.07 * * * \\
(-9.93)\end{array}$ & $\begin{array}{c}-0.21^{* * *} \\
(-29.36)\end{array}$ & $\begin{array}{l}-0.11^{* * *} \\
(-17.07)\end{array}$ & $\begin{array}{l}-0.24^{* * *} \\
(-36.95)\end{array}$ \\
\hline$\times 80 \%<\mathrm{CLTV} \leq 85 \%$ & $\begin{array}{c}-0.06^{* * *} \\
(-6.61)\end{array}$ & $\begin{array}{l}-0.21^{* * *} \\
(-21.30)\end{array}$ & $\begin{array}{l}-0.06^{* * *} \\
(-6.91)\end{array}$ & $\begin{array}{l}-0.20 * * * \\
(-24.05)\end{array}$ \\
\hline$\times 85 \%<\mathrm{CLTV} \leq 90 \%$ & $\begin{array}{l}-0.02 * * \\
(-2.99)\end{array}$ & $\begin{array}{c}-0.17 * * * \\
(-24.52)\end{array}$ & $\begin{array}{l}-0.04 * * * \\
(-5.64)\end{array}$ & $\begin{array}{l}-0.19 * * * \\
(-23.90)\end{array}$ \\
\hline$\times 90 \%<\mathrm{CLTV} \leq 95 \%$ & $\begin{array}{c}0.01 \\
(0.65)\end{array}$ & $\begin{array}{c}-0.15^{* * *} \\
(-14.40)\end{array}$ & $\begin{array}{l}0.02 \\
(1.82)\end{array}$ & $\begin{array}{l}-0.14^{* * *} \\
(-15.40)\end{array}$ \\
\hline$\times 95<$ CLTV $<=100$ & $\begin{array}{c}0.19^{* * *} \\
(6.97)\end{array}$ & $\begin{array}{c}0.01 \\
(0.23)\end{array}$ & $\begin{array}{l}0.10^{* * *} \\
(6.88)\end{array}$ & $\begin{array}{l}-0.08^{* * *} \\
(-5.23)\end{array}$ \\
\hline$\times 100<$ CLTV $<=105$ & & & $\begin{array}{l}0.22 * * * \\
(6.83)\end{array}$ & $\begin{array}{l}-0.00 \\
(-0.00)\end{array}$ \\
\hline$\times 105<$ CLTV $<=110$ & & & $\begin{array}{l}0.15^{* *} \\
(2.63)\end{array}$ & $\begin{array}{l}-0.11 \\
(-1.96)\end{array}$ \\
\hline$\times 110<\mathrm{CLTV}$ & & & & \\
\hline Interest rate polynomials & No & Yes & No & Yes \\
\hline Mortgage controls & Yes & Yes & Yes & Yes \\
\hline MSA × YYQQ FE & Yes & Yes & Yes & Yes \\
\hline Observations & $1,011,749$ & $1,011,749$ & $1,011,749$ & $1,011,749$ \\
\hline $\operatorname{Adj} R^{2}$ & 0.140 & 0.160 & 0.140 & 0.160 \\
\hline
\end{tabular}




\section{Table 7. Robustness Tests}

The table explores the possibility that the previous results are driven by selection. Panel A focuses on selection to the first transaction in the previous tests (purchase or refinance transactions). The panel uses a sample of triplets: three transactions for the same property. The first and third transactions are purchase transactions, and the second transactions can either be a purchase or refinance transaction. The dependent variable is the log difference between the third purchase transaction and the second purchase/refi transaction. Columns (4) to (6) include controls for the log difference in values of the second (purchase/refi) and the first (purchase) transactions. Panel B focuses on selection into the second (purchase) transaction in the previous tests. The panel uses a sample of refi transactions that have valuations produced by automated valuation models (AVMs). The dependent variable is the log difference between the appraisal value and the AVM. Defaulted and serious delinquency are dummies indicating whether the third transaction in the triplet (in Panel A) or the transaction (in Panel B) defaulted (90+ days past due) or was in serious delinquency (60+ days past due), respectively. Cash-out refi and Rate/term refi indicators describe the second transaction in the triplet (in Panel A) or the transaction of interest (in Panel B). Mortgage controls include information about the second transaction in the triplet (in Panel A) or the transaction of interest (in Panel B): FICO credit score (at origination), combined loan-to-value ratio (CLTV), short-term ARM indicator, hybrid ARM indicator, fixed rate 15-year mortgage indicator, fixed rate 30-year mortgage indicator, excess premium indicator, owner-occupier indicator, debt-to-income ratio, condo indicator, property size, property age, and tenure. MSA $\times$ YYQQ FE is MSA-quarter fixed effects. There are MSA-quarter fixed effects for the second and third transactions in the triplet (in Panel A) or the transaction of interest (in Panel B). Variable definitions are in Appendix A. All regressions are OLS regressions. Standard errors are clustered at the calendar quarter level. $t$-statistics are reported in parentheses. $* * *, * *$, and $*$ denote statistical significance at the $1 \%, 5 \%$, and $10 \%$ levels, respectively.

\section{Panel A: Controlling for Selection Drivers in the First Transaction}

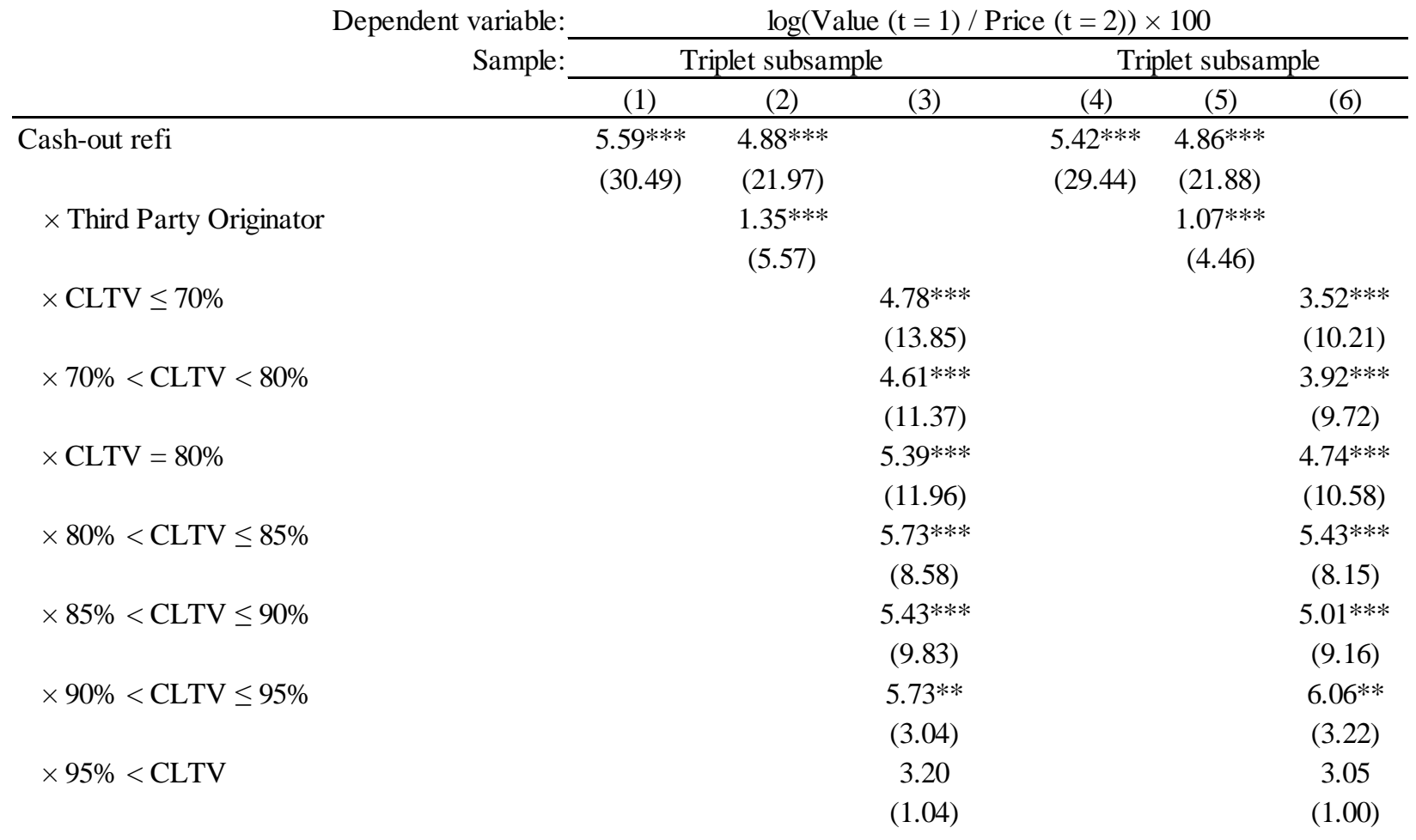

(continues on next page) 


\section{Table 7. Robustness Tests (Cont.)}

(continues from previous page)

\begin{tabular}{|c|c|c|c|c|c|c|}
\hline \multirow{3}{*}{$\begin{array}{r}\text { Dependent variable: } \\
\text { Sample: }\end{array}$} & \multicolumn{6}{|c|}{$\log ($ Value $(t=1) /$ Price $(t=2)) \times 100$} \\
\hline & \multicolumn{3}{|c|}{ Triplet subsample } & \multicolumn{3}{|c|}{ Triplet subsample } \\
\hline & $(1)$ & $(2)$ & (3) & $(4)$ & $(5)$ & $(6)$ \\
\hline$\ldots$ & & & & & & \\
\hline Rate/term refi & $\begin{array}{l}2.52^{* * *} \\
(15.86)\end{array}$ & $\begin{array}{c}1.55^{* * *} \\
(8.98)\end{array}$ & & $\begin{array}{l}4.06^{* * * *} \\
(24.74)\end{array}$ & $\begin{array}{l}3.14^{* * *} \\
(17.79)\end{array}$ & \\
\hline$\times$ Third Party Originator & & $\begin{array}{l}2.14^{* * *} \\
(14.40)\end{array}$ & & & $\begin{array}{l}1.98^{* * *} \\
(13.47)\end{array}$ & \\
\hline$\times \mathrm{CLTV} \leq 70 \%$ & & & $\begin{array}{c}1.34^{* * *} \\
(4.17)\end{array}$ & & & $\begin{array}{c}1.92^{* * *} \\
(6.00)\end{array}$ \\
\hline$\times 70 \%<\mathrm{CLTV}<80 \%$ & & & $\begin{array}{c}1.95^{* * *} \\
(5.36)\end{array}$ & & & $\begin{array}{c}2.97^{* * *} \\
(8.21)\end{array}$ \\
\hline$\times \mathrm{CLTV}=80 \%$ & & & $\begin{array}{c}2.91^{* * *} \\
(7.30)\end{array}$ & & & $\begin{array}{l}4.06^{* * *} \\
(10.26)\end{array}$ \\
\hline$\times 80 \%<\mathrm{CLTV} \leq 85 \%$ & & & $\begin{array}{c}2.92^{* * *} \\
(6.14)\end{array}$ & & & $\begin{array}{c}3.80^{* * *} \\
(8.09)\end{array}$ \\
\hline$\times 85 \%<\mathrm{CLTV} \leq 90 \%$ & & & $\begin{array}{c}2.00^{* * *} \\
(4.34)\end{array}$ & & & $\begin{array}{c}3.13^{* * * *} \\
(6.86)\end{array}$ \\
\hline$\times 90 \%<\mathrm{CLTV} \leq 95 \%$ & & & $\begin{array}{l}1.22^{*} \\
(2.31)\end{array}$ & & & $\begin{array}{c}2.62 * * * \\
(5.04)\end{array}$ \\
\hline$\times 95 \%<\mathrm{CLTV}$ & & & $\begin{array}{c}-1.14 \\
(-1.04)\end{array}$ & & & $\begin{array}{c}0.40 \\
(0.38)\end{array}$ \\
\hline $\log ($ Value $(t=1) /$ Price $(t=0))$ & & & & $\begin{array}{l}0.04^{* * *} \\
(14.84)\end{array}$ & $\begin{array}{l}0.04^{* * *} \\
(14.90)\end{array}$ & $\begin{array}{l}0.04^{* * *} \\
(14.41)\end{array}$ \\
\hline $\log ($ Value $(\mathrm{t}=1) /$ Price $(\mathrm{t}=0)) * \mathrm{I}(\operatorname{Refi}(\mathrm{t}=1))$ & & & & $\begin{array}{l}0.10^{* * *} \\
(20.04)\end{array}$ & $\begin{array}{l}0.09^{* * *} \\
(19.68)\end{array}$ & $\begin{array}{l}0.10^{* * *} \\
(21.13)\end{array}$ \\
\hline Defaulted + Serious delinquency indicators & Yes & Yes & Yes & Yes & Yes & Yes \\
\hline Mortgage controls & Yes & Yes & Yes & Yes & Yes & Yes \\
\hline MSA $\times$ YYQQ (first transaction) FE & Yes & Yes & Yes & Yes & Yes & Yes \\
\hline MSA $\times$ YYQQ (second transaction) FE & Yes & Yes & Yes & Yes & Yes & Yes \\
\hline Observations & 109,598 & 109,598 & 109,598 & 109,598 & 109,598 & 109,598 \\
\hline Adj $R^{2}$ & 0.279 & 0.281 & 0.281 & 0.293 & 0.294 & 0.295 \\
\hline
\end{tabular}


Table 7. Robustness Tests (Cont.)

Panel B: Using AVMs as Benchmark Valuations

\begin{tabular}{|c|c|c|c|}
\hline $\begin{array}{r}\text { Dependent variable: } \\
\text { Sample: }\end{array}$ & $\begin{array}{l}\text { og(Value } \\
\text { Refi subs }\end{array}$ & $\frac{\text { 1) / AVM }}{\text { le + refi }}$ & $\frac{=1)) \times 10}{\text { purchase }}$ \\
\hline & $(1)$ & (2) & (3) \\
\hline Cash-out refi & $6.94 * * *$ & $6.05^{* * *}$ & \\
\hline & (36.97) & (31.39) & \\
\hline$\times$ Third Party Originator & & $1.69^{* * *}$ & \\
\hline & & (19.84) & \\
\hline$\times \mathrm{CLTV} \leq 70 \%$ & & & $5.62 * * *$ \\
\hline & & & $(27.23)$ \\
\hline$\times 70 \%<\mathrm{CLTV}<80 \%$ & & & $6.79 * * *$ \\
\hline & & & (33.86) \\
\hline$\times \mathrm{CLTV}=80 \%$ & & & $7.62^{* * *}$ \\
\hline & & & (36.59) \\
\hline$\times 80 \%<\mathrm{CLTV} \leq 85 \%$ & & & $7.60^{* * *}$ \\
\hline & & & $(26.29)$ \\
\hline$\times 85 \%<\mathrm{CLTV} \leq 90 \%$ & & & $6.42^{* * *}$ \\
\hline & & & $(28.28)$ \\
\hline$\times 90 \%<\mathrm{CLTV} \leq 95 \%$ & & & $4.85^{* * *}$ \\
\hline & & & $(7.46)$ \\
\hline$\times 95 \%<\mathrm{CLTV}$ & & & $4.14^{* * *}$ \\
\hline & & & $(5.46)$ \\
\hline Rate refi & $3.67 * * *$ & $2.56^{* * *}$ & \\
\hline & (19.27) & (13.33) & \\
\hline$\times$ Third Party Originator & & $2.28 * * *$ & \\
\hline & & (32.21) & \\
\hline$\times \mathrm{CLTV} \leq 70 \%$ & & & $2.46^{* * *}$ \\
\hline & & & $(11.64)$ \\
\hline$\times 70 \%<$ CLTV $<80 \%$ & & & $2.95^{* * *}$ \\
\hline & & & $(14.83)$ \\
\hline$\times \mathrm{CLTV}=80 \%$ & & & $4.15^{* * *}$ \\
\hline & & & (20.03) \\
\hline$\times 80 \%<\mathrm{CLTV} \leq 85 \%$ & & & $5.22^{* * *}$ \\
\hline & & & $(20.62)$ \\
\hline$\times 85 \%<\mathrm{CLTV} \leq 90 \%$ & & & $3.89 * * *$ \\
\hline & & & $(18.32)$ \\
\hline$\times 90 \%<\mathrm{CLTV} \leq 95 \%$ & & & $3.53^{* * *}$ \\
\hline & & & $(14.79)$ \\
\hline$\times 95 \%<\mathrm{CLTV}$ & & & $3.09 * * *$ \\
\hline & & & $(7.22)$ \\
\hline Defaulted + Serious delinquency indicators & Yes & Yes & Yes \\
\hline Mortgage controls & Yes & Yes & Yes \\
\hline MSA $\times$ YYQQ (first transaction) FE & Yes & Yes & Yes \\
\hline MSA $\times$ YYQQ (second transaction) FE & Yes & Yes & Yes \\
\hline Observations & 441,132 & 441,132 & 441,132 \\
\hline $\operatorname{Adj} R^{2}$ & 0.043 & 0.047 & 0.044 \\
\hline
\end{tabular}


Figure 1. Origination of $\mathbf{1 0 0 \%}$ Loan-to-Value Mortgages

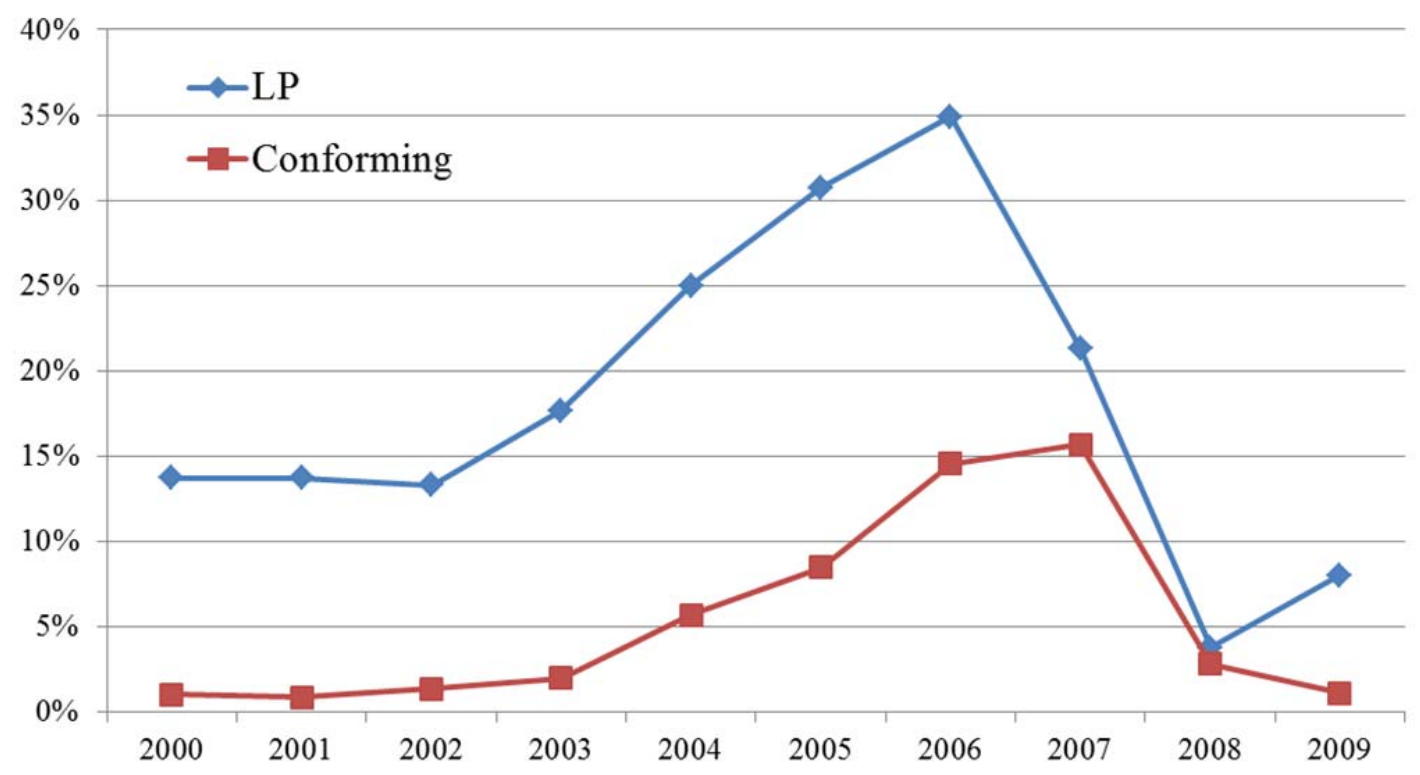

The figure shows the fraction of loans (purchase and refinance) that were originated at 100\% LTV. The data used is the universe of mortgages in Loan Performance (LP; subprime and Alt-A securitized mortgages) and confirming loans (the dataset that is used in this study). 